\title{
Increase in Nuisance Blooms and Geographic Expansion of the Freshwater Diatom Didymosphenia geminata
}

By S.A. Spaulding and L. Elwell

Open-File Report 2007-1425

U.S. Department of the Interior

U.S. Geological Survey

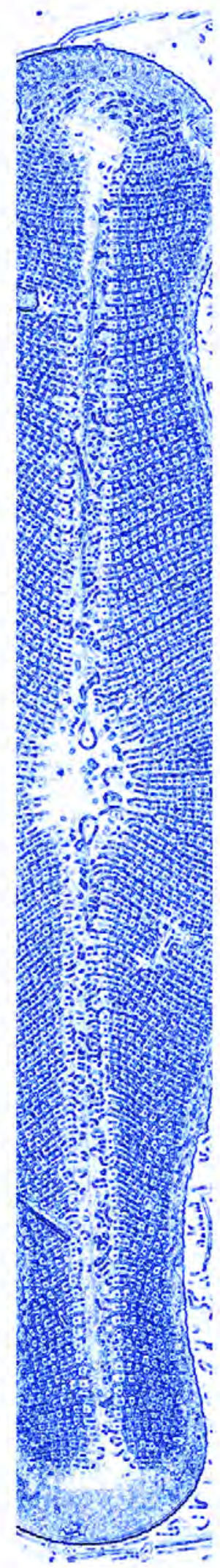




\section{U.S. Department of the Interior \\ DIRK KEMPTHORNE, Secretary}

\section{U.S. Geological Survey \\ Mark D. Myers, Director}

U.S. Geological Survey, Reston, Virginia 2007

For product and ordering information:

World Wide Web: http://www.usgs.gov/pubprod

Telephone: 1-888-ASK-USGS

For more information on the USGS - the Federal source for science about the Earth, its natural and living resources, natural hazards, and the environment:

World Wide Web: http://www.usgs.gov

Telephone: 1-888-ASK-USGS

Suggested citation:

Spaulding, S.A., and Elwell, L., 2007, Increase in nuisance blooms and geographic expansion of the freshwater diatom Didymosphenia geminata: U.S. Geological Survey Open-File Report 2007-1425, 38 p.

Any use of trade, product, or firm names is for descriptive purposes only and does not imply endorsement by the U.S. Government.

Although this report is in the public domain, permission must be secured from the individual copyright owners to reproduce any copyrighted material contained within this report. 


\section{Contents}

Executive Summary

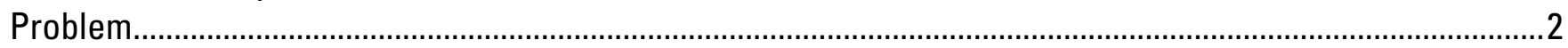

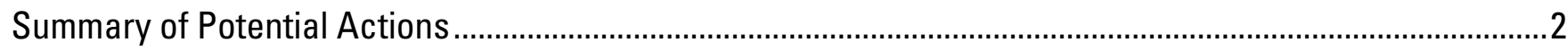

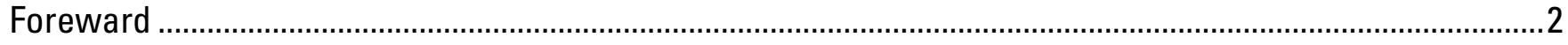

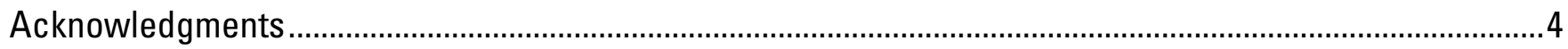

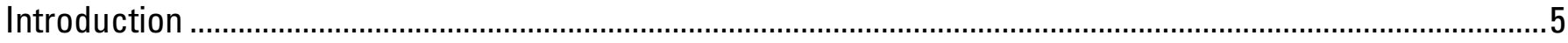

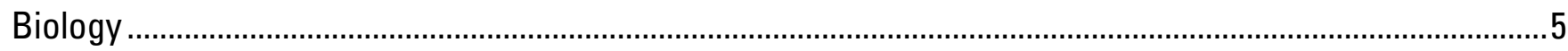

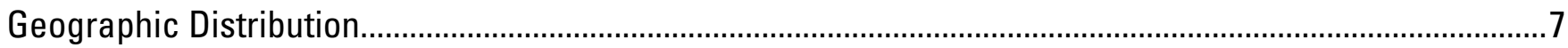

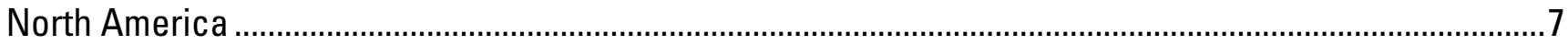

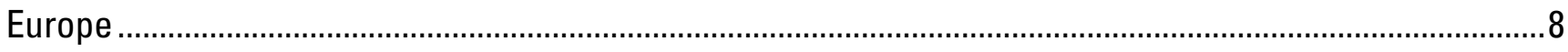

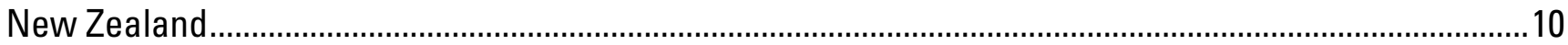

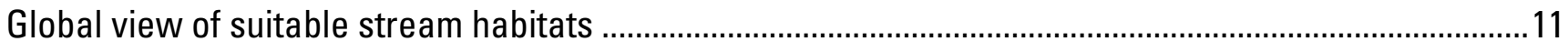

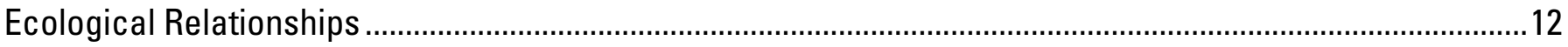

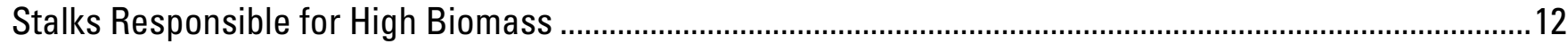

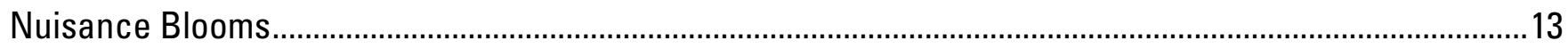

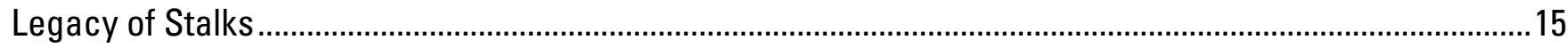

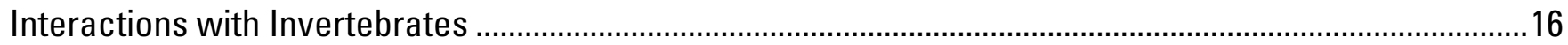

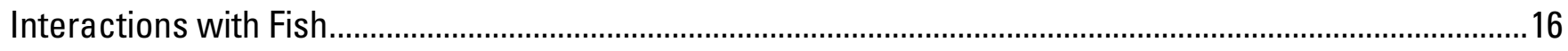

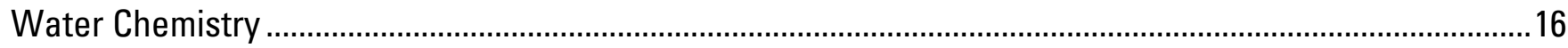

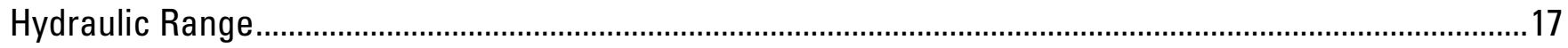

A Biological Paradox

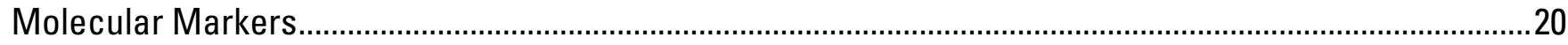

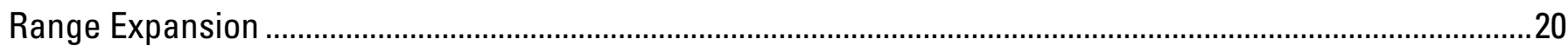

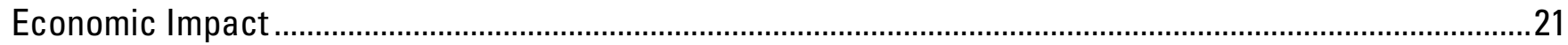

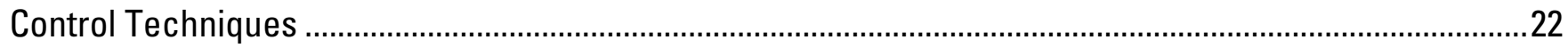

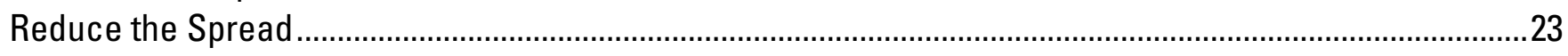

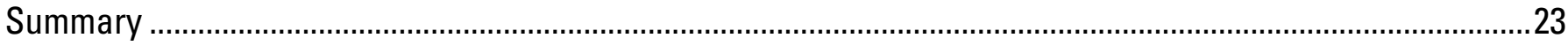

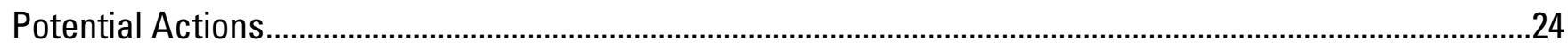

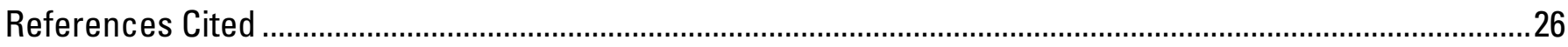

Glossary

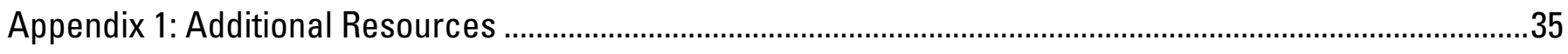

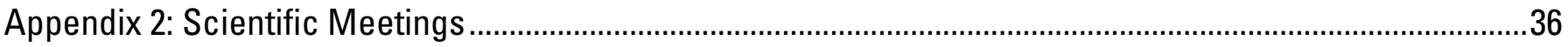

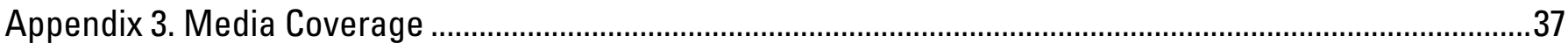




\section{Figures}

1. $A, D$. geminata cell shown under the light microscope. $B$, Typical growth habit on cobble substrate. $C$,

Distribution records in North America

2. $A$, Stream cobble with dense mat D. geminata. $B$, Streambed with dense mats. $C$, Dried stalks, exposed after high water

3. Scanning electron micrograph of the cell wall of $D$. geminata ...................................................................

4. Scanning electron micrograph of $D$. geminata and stalks .....................................................................

5. Biochemical composition of three fractions $D$. geminata stalk ..................................................................

6. Confirmed presence and absence records of $D$. geminata in the United States..........................................

7. Confirmed presence and portion of published global records of $D$. geminata .............................................. 10

8. Confirmed presence of $D$. geminata in New Zealand.............................................................................11

9. Map of the world showing regions where suitable stream habitats for $D$. geminata are predicted, based

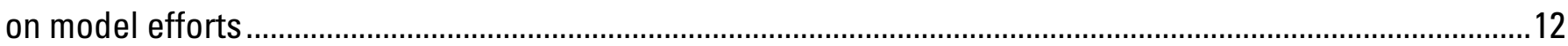

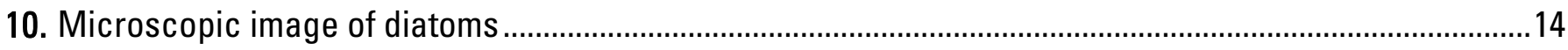

11. Rock coated with $D$. geminata stalks and fine sediment................................................................. 15

12. $A$, Water temperature versus frequency of sites with $D$. geminata. $B, \mathrm{pH}$ versus frequency of sites with

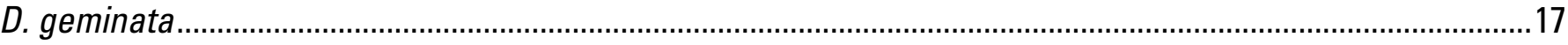

13. $A$, Conductance versus frequency of sites with $D$. geminata $B$, Acid neutralizing capacity versus frequency of sites with $D$. geminata .................................................................................................. 18

14. $A$, Total phosphorus versus frequency of sites with $D$. geminata. $B$, Nitrate versus frequency of sites with $D$. geminata

15. Water velocity versus. visual biovolume index in the Mararoa River, New Zealand..................................19

16. Image of waders in stream with substrate covered by D. geminata.........................................................21

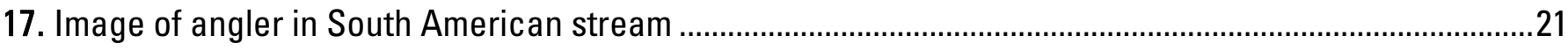

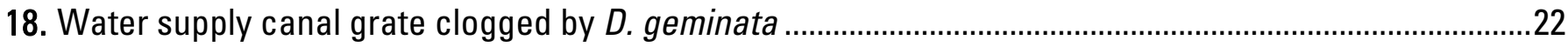

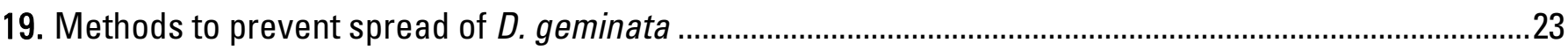

\section{Tables}

1. Minimum and maximum ash free dry mass and chlorophyll a

2. Sites in the United States and Canada that are considered to contain nuisance blooms ............................14 


\title{
Increase in Nuisance Blooms and Geographic Expansion of the Freshwater Diatom Didymosphenia geminata
}

\author{
By S.A. Spaulding and E. Elwell
}

\section{Executive Summary}

The diatom Didymosphenia geminata (Lyngbye) Schmidt is emerging as an organism with an extraordinary capacity to impact stream ecosystems on a global scale. In recent years, streams in New Zealand, North America, Europe, and Asia have been colonized by unprecedented masses of "didymo" and its extracellular stalks (fig. 1). This diatom is able to dominate stream surfaces by covering up to 100 percent of substrate with thicknesses of greater than $20 \mathrm{~cm}$, greatly altering physical and biological conditions within streams. This species is expanding its geographic range in North America and the rate that nuisance blooms are reported by the public and local media are increasing, yet little scientific investigation of the phenomenon in North America has been initiated.
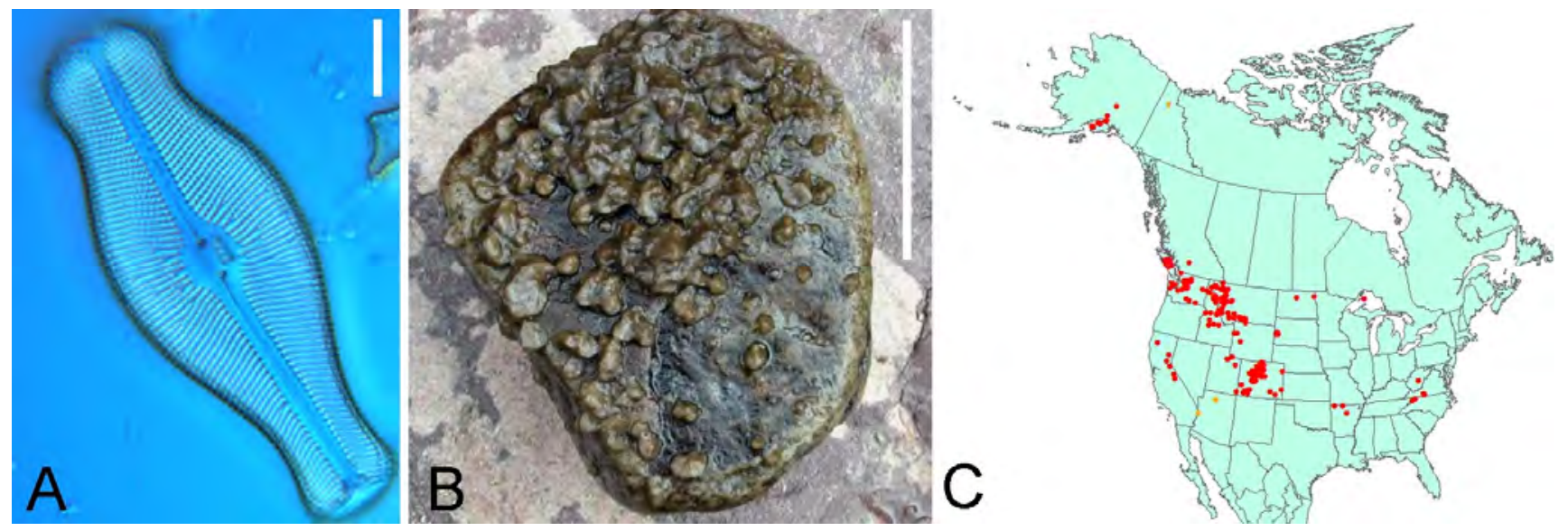

Figure 1. $A$, Image of $D$. geminata cell under the light microscope. Scale bar is equal to 10 microns. $B$, Cobble from stream showing typical growth habit. Scale bar is approximately $10 \mathrm{~cm}$. $C$, Map showing the confirmed distribution records of D. geminata in North America, as of August 2006. 


\section{Problem}

A global community of scientists, land managers, and anglers have reached consensus U.S. views on realized and potential threats of Didymosphenia geminata. We recognize a growing body of evidence that $D$. geminata is:

- the only freshwater diatom to exhibit large scale invasive behavior and a persistent phenomenon on a global scale;

- a species with the biological capacity to produce inordinate amounts of stalk material (extracellular mucopolysaccarides) with unique properties;

- a significant biological impact to stream ecosystem function with the ability to alter foodweb structure and hydraulics of streams and rivers;

- an organism that has expanded its ecological range and tolerance;

- exhibiting a pattern of growth with potential impact to fisheries

- a significant strain on regional and national economies through impacts to tourism, fisheries, and hydropower; and

- an organism for which we lack basic biological and ecological knowledge.

\section{Summary of Potential Actions}

An aggressive education and outreach program could change user behavior and minimize spread of $D$. geminata on a global scale.

- Determine if there has been a genetically based physiological change in D. geminata that is linked to a nuisance strain. Molecular markers present the opportunity to trace the relationships among nuisance outbreaks, and those records can be compared with models of predicted global distribution.

- Determine the degree to which the spread of $D$. geminata is aided by specific human vectors on waders or other gear.

- Track the geographic distribution of D. geminata on a global scale using effective and proper documentation of sites and voucher material.

- Determine the ecological conditions under which excessive biomass is produced in low nutrient streams and rivers, over short periods of time.

- Develop strategies to mitigate existing blooms.

- Determine the unique composition, structure, and cellular processes that produce the $D$. geminata stalk, which is responsible for its negative ecosystem impacts.

- Evaluate the apparent resistance of the stalk to degradation by bacteria and fungi, and determine ecosystem effects of stalk material.

- Verify the direct and indirect impacts of D. geminata and its stalks on aquatic macroinvertebrates and fish.

- Resolve the impacts of D. geminata at both high and low densities and determine whether there are threshold levels of nuisance growths.

\section{Foreward}

In May 2006, a concerned group of international scientists; resource managers; aquatic professionals; conservation groups; consulting firms; and State, Federal and Tribal agencies gathered to bring together the current knowledge of the diatom Didymosphenia geminata. This meeting was exceptional for the diversity of interests of participants, joined by a common concern about a rather small organism and its behavior and potential impacts. This report is an outcome of that meeting 
and the expressed need by participants to document the issues and make suggestions in responding to the change in behavior of $D$. geminata. We hope this document provides a basis to address research and management needs and to stimulate understanding of an amazing biological phenomenon.

Terms shown in bold within the text are defined in the Glossary (page 32).

International Didymosphenia Symposium, in association with the American Fisheries Society - Western Division annual meeting, Bozeman, Montana 2006

\section{Participant Affiliations}

Government

Arkansas Department of Environmental Quality

Arkansas Game and Fish Commission

Biosecurity New Zealand

Environment Canada

Montana Fish, Wildlife, and Parks

National Institute of Water and Atmospheric Research (New Zealand)

South Dakota Department of Environmental Quality

South Dakota Game, Fish, and Parks

U.S. Army Corps of Engineers

U.S. Environmental Protection Agency (EPA)

U.S. Forest Service

U.S. Geological Survey (USGS)

Washington State Department of Ecology

Wyoming Game and Fish

Tribal

Blackfeet Environmental Office (Montana)

Wind River Environmental Quality Commission (Wyoming)

Private

ADVENT-ENVIRON (United States)

Battelle Energy Alliance (United States)

British Columbia Conservation Foundation (Canada)

Bowburn Consultancy (United Kingdom)

Central Arizona Project (United States)

Chadwick Ecological Division of GEI Consultants, Inc. (United States)

Drake and Associates, Inc. (United States)

Eco-Analysts, Inc. (United States)

Kuipers and Associates (United States)

Meridian Energy (New Zealand)

Rhithron Associates, Inc. (United States)

Stillwater Mining Company (United States) 
Non-Profit

Black Hills Flyfishers (South Dakota)

Federation of Fly Fishers (United States)

Northern Plains Resource Council (Montana)

Whirling Disease Initiative (Montana)

University/Research Institutions

Colorado State University

Desert Research Institute (Nevada)

Institute of Freshwater Fisheries (Iceland)

Michigan Technological University

Portland State University

University of Calgary

University of Colorado

University of Delaware

University of Nevada

\section{Acknowledgments}

This work could not been completed without the generous contributions of the Federation of Fly Fishers, EPA, and many individuals. The International Didymosphenia Symposium was supported by the Trout and Salmon Foundation, the Black Hills Flyfishers, and the Overmountain Chapter of Trout Unlimited. Thanks to Barry Biggs, National Institute of Water and Atmospheric Research, New Zealand; Dave Beeson, ADVENT-ENVIRON; Max Bothwell, Environment Canada; Craig Cary, University of Waikato, New Zealand; Michael Gretz, Michigan Technological University; Karl Hermann, EPA; Ingi Jónssen, Iceland Institute of Freshwater Fisheries, Iceland; Martyn Kelly, Bowburn Consultancy, United Kingdom; Cathy Kilroy, National Institute of Water and Atmospheric Research, New Zealand; Diane McKnight, University of Colorado; Sheila Murphy, USGS; Kristina McNyset, EPA; Yang Don Pan, Portland State Univerisity; Peter Pryfogle, Idaho National Laboratory; Travis Schmidt, Colorado State University; Erica Shelby, Arkansas Department of Environmental Quality; Jan Stevenson, Michigan State University; Christina Vieglais, Biosecurity New Zealand; Rich Wanty, USGS and Robert Wiltshire, Federation of Fly Fishers. 


\section{Introduction}

Didymosphenia geminata (Lyngbye) Schmidt was originally described from specimens of the Faroe Islands. This diatom was very common in Scotland, Sweden and Finland (Cleve, 18941896), and in the Kanchou region of China, D. geminata formed massive accumulations (Skvortzow, 1935). While historic growth patterns include episodic formation of large masses, growth patterns now differ by having greater spatial coverage and temporal persistence. Until recently, this diatom was restricted to low nutrient waters, but now it occurs in more nutrient-rich streams and rivers. In many regions of North America, D. geminata now forms nuisance benthic growths that extend beyond $1 \mathrm{~km}$ and persist for several months of the year. Furthermore, D. geminata has appeared to expand its geographic range within North America and Europe and recently has invaded New Zealand. Under nuisance bloom conditions, D. geminata cells produce copious amounts of extracellular stalk material that form thick benthic mats. To the observer, these mats appear as fiberglass insulation, tissue paper, "rock snot," brown shag carpet, or sheep skins covering the streambed (fig. 2).
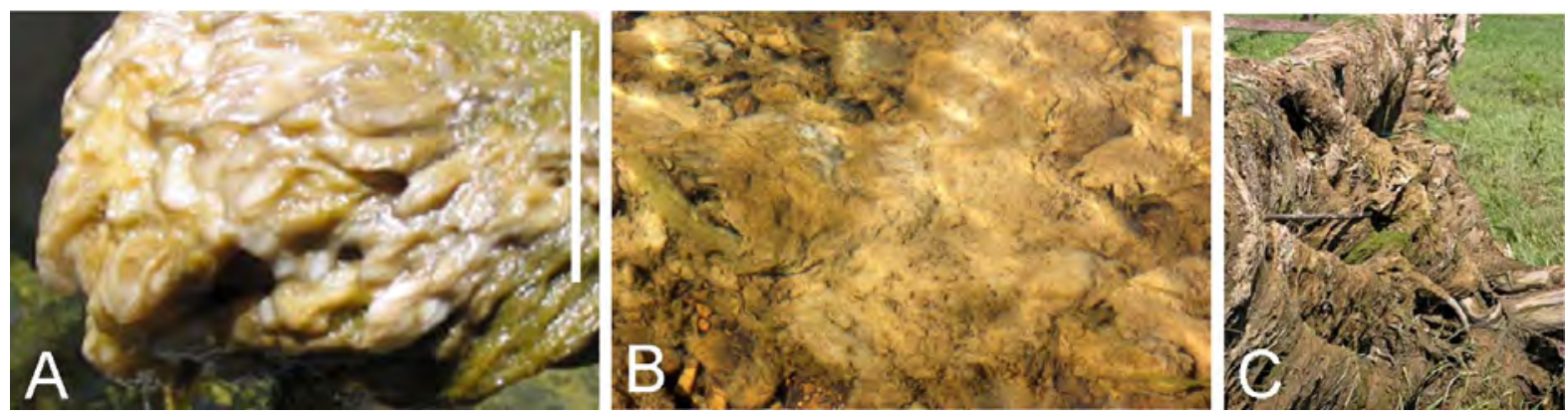

Figure 2. $A$, Stream cobble covered with $D$. geminata and stalks $5 \mathrm{~cm}$ thick. Scale bar approx. 10 $\mathrm{cm}$. $B$, Streambed covered with $D$. geminata. Note that rocks and cobbles are hardly visible. Scale bar approx. $10 \mathrm{~cm}$. C, Dried stalks on dock structures. (Images by Erica Shelby, Arkansas Department of Environmental Quality.)

\section{Biology}

Didymosphenia geminata is a diatom, a type of single-celled algae. Diatoms are remarkable organisms, unique for their silica $\left(\mathrm{SiO}_{2}\right)$ cell walls, which are often well-preserved in sediments making diatoms useful as environmental indicators (Smol and Stoermer, 1998). Diatoms are found in nearly every freshwater and marine aquatic habitat and contribute a large percentage of the global carbon budget through photosynthesis. In both oceans and freshwaters, diatoms are one of the major groups of organisms within the plankton assemblage and also grow attached to surfaces. Diatoms store chrysolaminarin (ß1,3 linked glucan) as well as accumulate lipid within the cell. Lipids are an oil-rich source of energy, which make diatoms a valuable food for other organisms. The life history of diatoms includes both vegetative and sexual reproduction (reviewed in Edlund and Stoermer, 1997), although the sexual stage has not been documented in D. geminata (but see Skabichevsky, 1983). 
Valve morphology of the genus. Didymosphenia has been well documented (Dawson, 1973a, b; Antoine and Benson-Evans, 1983; Stoermer and others, 1986; Metzeltin and LangeBertalot, 1995). Didymosphenia is considered within the cymbelloid, rather than gomphonemoid, lineage of diatoms (Kociolek and Stoermer, 1993). Cells possess a raphe, a structure that allows the cells to move on surfaces. The cells also possess an apical porefield, through which a mucopolysaccaride stalk is secreted (fig. 3). The stalk may attach to rocks, plants, or any other submerged substrate. When the diatom cell divides (that is, through vegetative reproduction), the stalk also divides, eventually forming a dense mass of branching stalks. It is not the diatom cell itself that is responsible for the negative impacts of $D$. geminata, but the massive production of extracellular stalk (fig. 4).

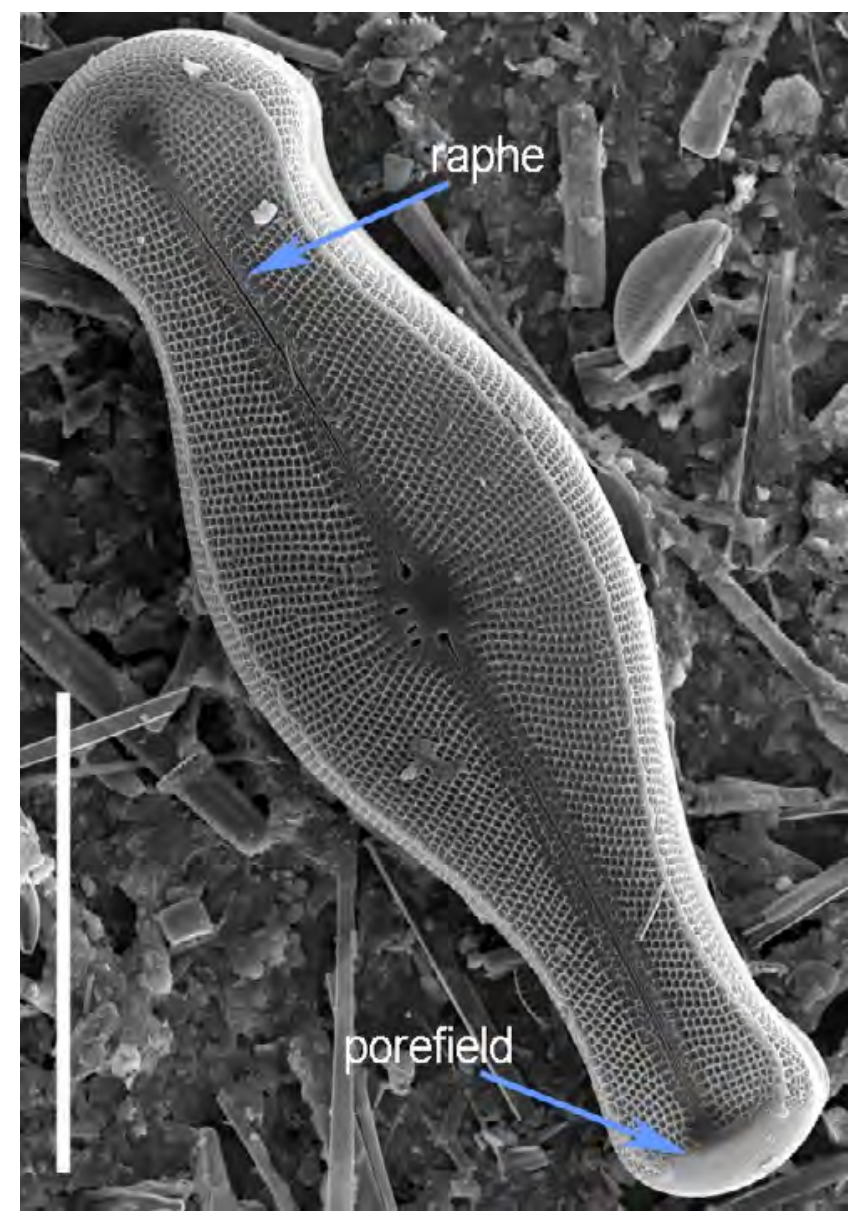

Figure 3. Scanning electron micrograph of the silica cell wall of $D$. geminata. The raphe is composed of the two slits that run along the apical axis of the cell. The cell secretes mucopolysaccarides through the raphe in order to move on surfaces. At the base of the cell is the porefield, through which the stalk is secreted. Scale bar equal to $50 \mu \mathrm{m}$. (Image by Sarah Spaulding, USGS.) 


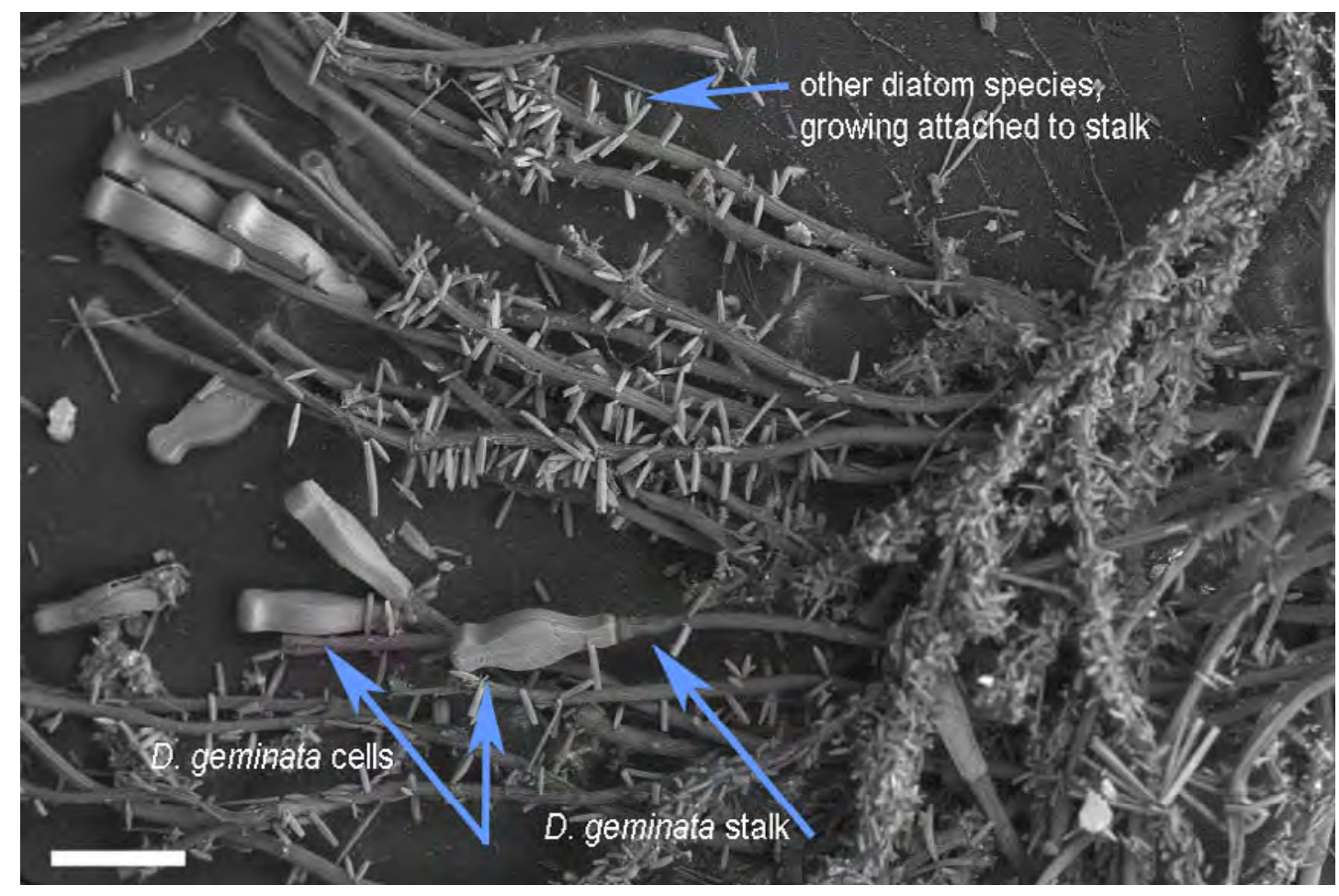

Figure 4. Scanning electron micrograph of $D$. geminata cells and their mucopolysaccaride stalks. The stalks produced within the cell are many times the length of the cell itself. Note the smaller diatoms growing attached to the stalks. Scale bar equal to $100 \mu \mathrm{m}$. (Image by Sarah Kiemle, Michigan Technological University.)

Extracellular polymeric substances (EPS) that make up the stalk are predominantly composed of polysaccarides and protein (fig. 5). They are complex, multilayered structures that are resistant to degradation. The degree to which internal (genetic) and external (environmental) changes initiate the high level of stalk production is unknown, yet resolving the mechanisms of stalk production is crucial for determining ecological impacts, physiological regulation, and control of D. geminata. We have little understanding of the biology and ecological roles of D. geminata, and we need basic information to determine the causes and conditions that lead to nuisance blooms and the geographic expansion of this diatom.

\section{Geographic Distribution}

\section{North America}

In North America, historical reports of D. geminata are sparse and voucher specimens are uncommon. Although it is not possible to state the historical range of this diatom with confidence, historical distributions were considered to be northern circumboreal in cold, oligotrophic waters. The earliest published records of D. geminata from North America were on Vancouver Island, British Columbia (Cleve, 1894-1896) although it contains no notes on its abundance. Nearly one hundred years later, D. geminata formed nuisance blooms in Vancouver Island's Heber River and over a period of years, nuisance blooms appeared in two-thirds of the island's rivers (Sherbot 


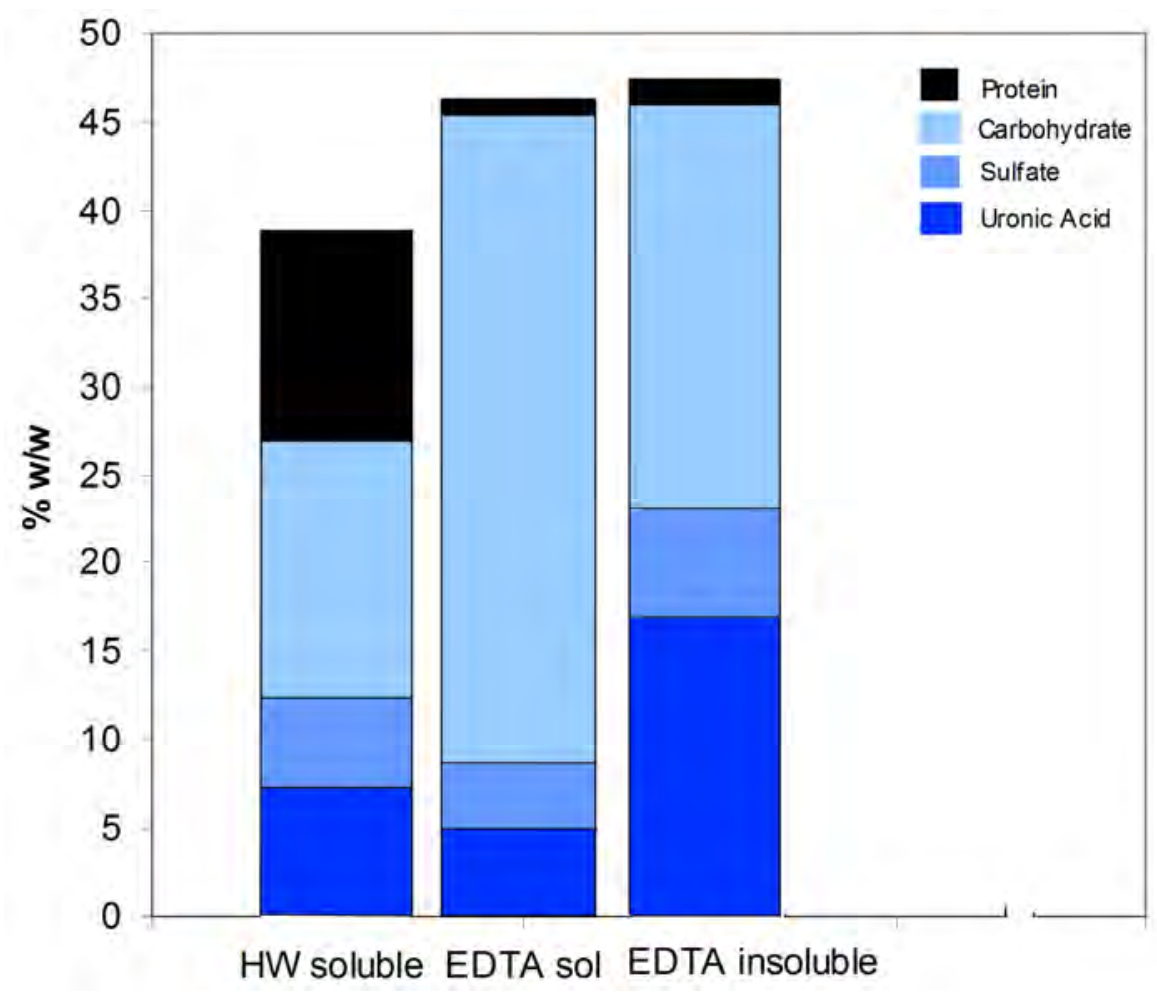

Figure 5. Biochemical composition by weight percent $(\% \mathrm{w} / \mathrm{w})$ of three fractions of the $D$. geminata stalk: hot water soluble (HW soluble), EDTA soluble (EDTA sol), EDTA insoluble (EDTA insoluble). The three fractions differ in their percentage composition of uronic acid, sulfate compounds, carbohydrate, and protein. (Data from Michael Gretz, Michigan Technological University, unpublished data, 2006.)

and Bothwell, 1993). In "The Diatoms of the United States," Patrick and Reimer (1975) reported only one state, Virginia, as the distribution for D. geminata in the United States. More recent works consider D. geminata as present in rivers in the western United States (Bahls, 2004).

A pattern of expanding range and nuisance populations has developed in North America over the past several years (fig. 6) (Pryfogle and others 1997; Holderman and Hardy 2004; Shelby, 2006), as well as in Europe and New Zealand (fig. 7).

\section{Europe}

In European countries, reports are variable concerning the extent of $D$. geminata in streams and rivers. Northern and western rivers of the United Kingdom are subject to large masses of $D$. geminata, but the growths are considered to be a natural phenomenon and have been recorded for over 150 years. There are no reports of geographic expansion or increase in biomass of D. geminata (Skwortzow and Meyer, 1928; Whitton and Crisp, 1984; Lindstrom, 1991; Bukhtiyarova, 1999). Likewise, although masses of $D$. geminata increased with the regulation of streamflow (Skulberg, 1982), the formation of blooms is considered a normal event. 


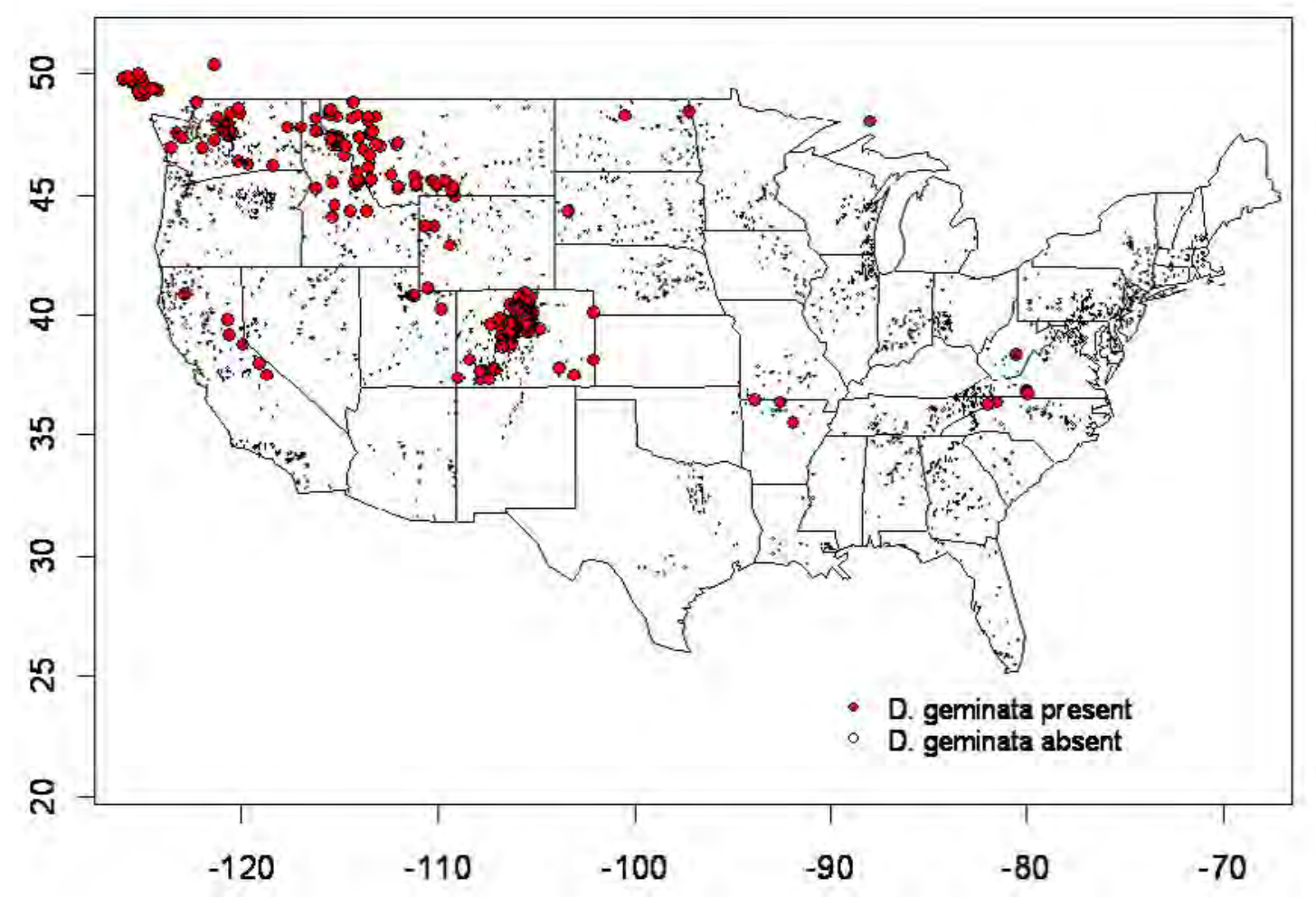

Figure 6. Confirmed presence and absence records of $D$. geminata in the United States. A total of 4,569 samples were included, and D. geminata is present in 283 sites. Records are based on data from the USGS National Water Quality Assessment (NAWQA), the EPA Environmental Monitoring and Assessment Program (EMAP), and samples from other studies. (Map by Sarah Spaulding, USGS.)

In Icelandic rivers, D. geminata formed large blooms beginning in the early 1990s (Jónssen and others, 2000). Blooms had no relation to bedrock geology or specific conductance, that is, the distribution and biomass of extensive mats appeared to be unrelated to water chemistry. Icelandic rivers are vital to the salmon fishery and there was concern that the masses of D. geminata would negatively impact spawning. Although salmon populations have decreased over the last decade in Iceland, the cause has not been determined, and it may be difficult to separate the influence of oceanic events from algal mats on salmon populations. Since the 1990s, populations of D. geminata in some locations have either decreased, or remained stable.

High abundances of D. geminata were documented in several rivers of the Carpathian, Gorce, and Tatra Mountains of Poland (Kawecka and Sanecki 2003; Noga, 2003). Observations of extensive growths and their expansion to new watersheds were contrasted to observations from the 1960 s when $D$. geminata was present but occurred in low abundance. The rivers where $D$. geminata formed large masses in recent years are impacted by anthropogenic nutrient input, with river concentrations of nitrate $\left(\mathrm{NO}_{3}\right)$ ranging from 1.7 to $3.8 \mathrm{mg} / \mathrm{L}$ and phosphate $\left(\mathrm{PO}_{4}\right)$ ranging from 13 to $100 \mu \mathrm{g} / \mathrm{L}$ (Kawecka and Sanecki, 2003). The discovery of nuisance D. geminata populations in 


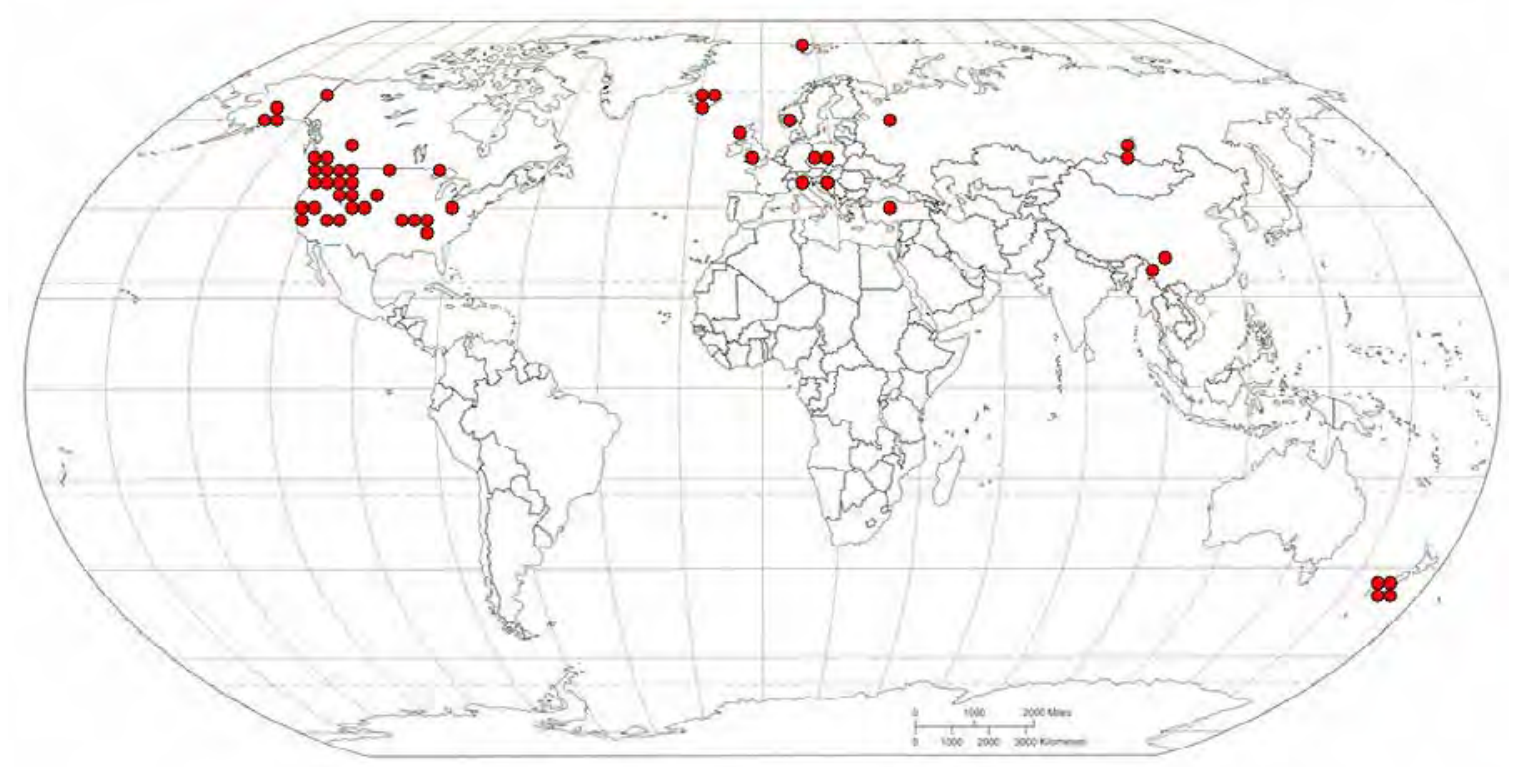

Figure 7. Confirmed presence and portion of published records of $D$. geminata from around the world. Dots do not represent number of reports, but show rough geographic area of populations. (Map by Sarah Spaulding, USGS.)

high nutrient waters was the first recognition that the species was appearing outside its recognized ecological range.

Similar to rivers in Poland, the eutrophic Tisa River in Serbia was reported to contain $D$. geminata throughout most of the year (March through November) (Subakov-Simić and Cvijan, 2004). The Tisa River had temperatures above $20^{\circ} \mathrm{C}$ for three months of the year, as well as high concentrations of ammonia $\left(\mathrm{NH}_{3}\right)(0.67 \mathrm{mg} / \mathrm{l})$ and metals. Simić and Cvijan also present evidence that $D$. geminata is able to grow well at high temperatures and in polluted sites. Such a finding is repeated in the Değirmendere River in Turkey, where irrigation return flows, municipal wastes, and other inputs heavily influence water chemistry (Kara and Şahin, 2001). At this site, D. geminata was found in high abundance for several months of the year.

\section{New Zealand}

The first confirmed record of D. geminata in the southern hemisphere was in October 2004, in the lower Waiau River of the South Island of New Zealand (Kilroy, 2004). Despite a proactive response of containment by the New Zealand government, within 18 months $D$. geminata spread to 12 rivers on the South Island (fig. 8) and formed excessive blooms in several sites. The blooms in New Zealand demonstrate that $D$. geminata is an aggressive invasive species with dramatic ecological, economic, social, hydropower, recreational, and aesthetic impacts (Kilroy and others 2005a, b, c, 2006; Campbell, 2005; Branson, 2006). Biosecurity New Zealand, the branch of government responsible for invasive species, identified $D$. geminata as harmful and of great concern. There is widespread agreement that $D$. geminata was introduced through human activity, in fact, penalties of up to five years imprisonment and a fine of $\$ N Z 100,000$ are in place for intentionally spreading $D$. geminata. As of November $2006, D$. geminata has not been confirmed in any locations on the North Island of New Zealand. 


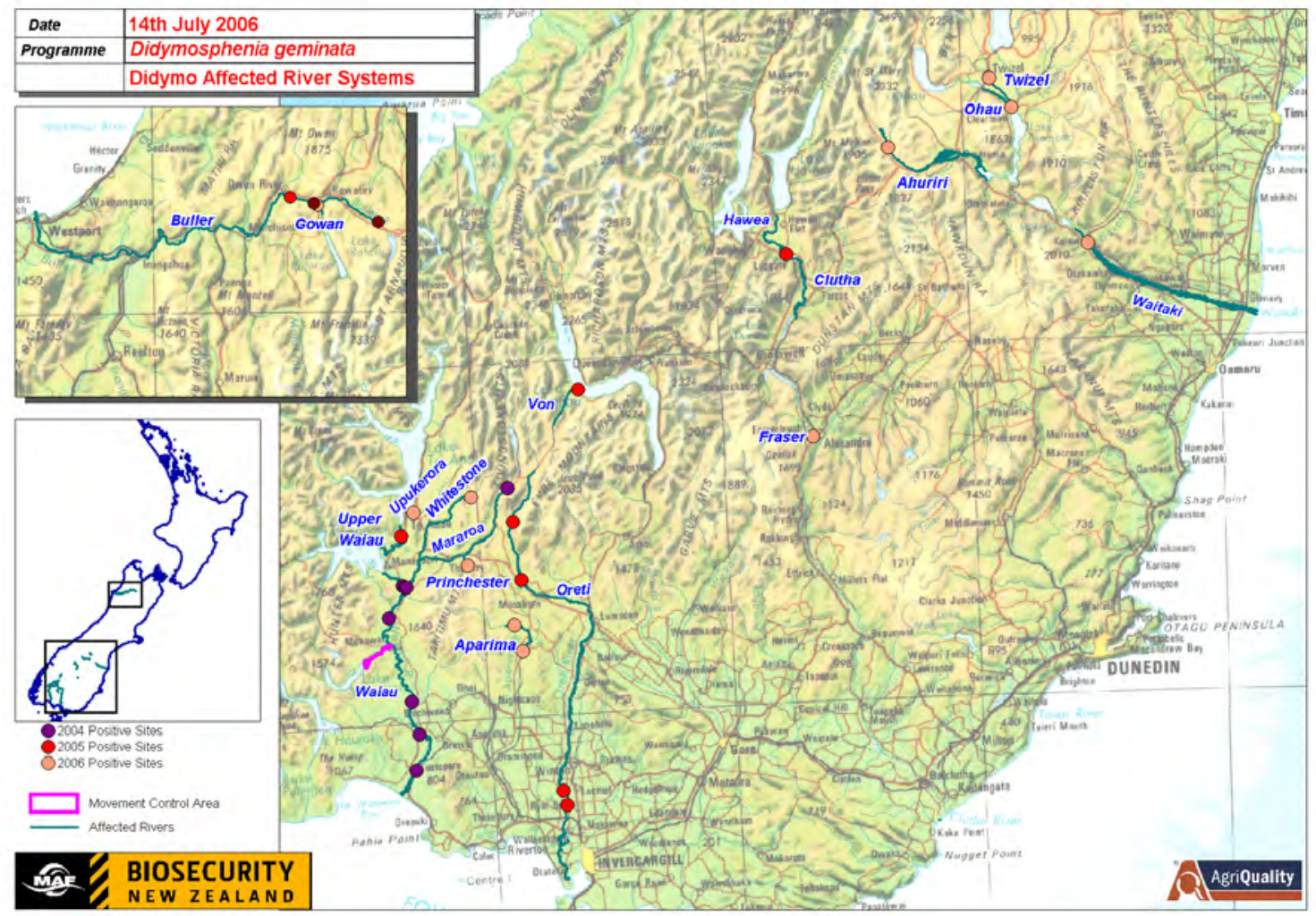

Figure 8. Confirmed presence of D. geminata in New Zealand as of July 2006 (www.biosecurity.govt.nz/didymo).

Prior to the incursion in New Zealand, knowledge of ecosystem roles and impacts of $D$. geminata was primarily anecdotal (Kilroy, 2004). At the present time, several scientific and technical studies have been completed or are in progress that address identification, detection, distribution, containment, impact, and control or eradication of D. geminata in New Zealand (see Appendix 1 for the Biosecurity New Zealand website). As a result of work in New Zealand, the ability of $D$. geminata to survive outside water and the requirements to decontaminate aquatic gear of live cells have been experimentally established. The range of $D$. geminata in terms of hydraulic habitat, temporal changes in biomass, and relation to density of benthic invertebrates has been investigated (Kilroy and others, 2005a). The interaction of flows and the likelihood of D. geminata transport to vital hydropower sites in Lake Manapouri were established (Biggs and others, 2005, Sutherland and others, 2005). Studies to determine the effects of D. geminata on native fish and invertebrates (benthic and drift) and water quality (dissolved oxygen and $\mathrm{pH}$ ) are in progress. Other studies will address impacts of $D$. geminata on productivity of trout, develop molecular detection methods, and establish efficient monitoring efforts.

\section{Global view of suitable stream habitats}

A global distribution map based on ecological niche models shows suitable stream habitats for D. geminata on every continent except Antarctica (fig. 9) (McNyset and Julius, 2006). While 


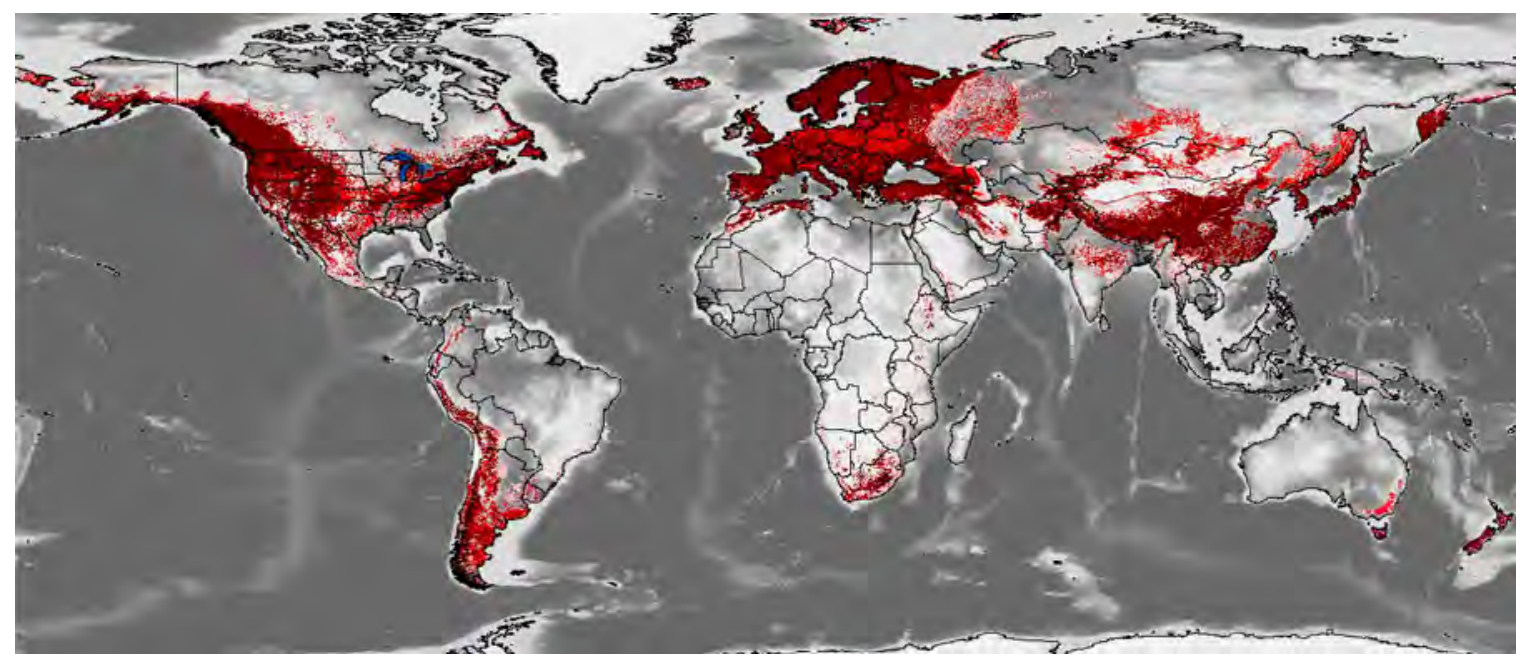

Figure 9. Map of the world showing regions where suitable stream habitats for $D$. geminata are predicted, based on model efforts. This map presents a very different picture from the previous account of $D$. geminata in the United States. Results for Australia are preliminary. (Map by Kris McNyset, U.S. Environmental Protection Agency.)

historical records in North America are poor, this map presents very different picture from the previous account of D. geminata in the United States (given in the lower 48 United States as Virginia in Patrick and Reimer, 1975). We now know that D. geminata can thrive in a wide range of physical and chemical conditions within rivers and spread by humans is of concern. Rivers in the Southern Hemisphere are particularly at risk to new introduction and invasion. Appropriate agency personnel in Australia, Argentina, Chile and Peru could be notified and made aware of the potential ecological damage and the urgency of implementing a decontamination procedure.

\section{Ecological Relationships}

The physical, chemical, and biological properties of streams and their organisms are intimately tied (Hynes, 1975). Didymosphenia geminata both influences the stream environment and is controlled by environmental features. This diatom is capable of producing such great amounts of stalk that the mats covering the stream bed result in changes in ecological properties of the stream (for example, species diversity, population sizes, nutrient pools) (Larned and others, 2006). Algal, invertebrate, and fish species diversity and population sizes may be altered. In addition, high growth rates and extensive mats of D. geminata may impact ecological processes such as ecosystem metabolism and nutrient cycling. Stalk and algal biomass, formation of nuisance blooms, legacy of stalks, interactions with invertebrates, interactions with fish, control by water chemistry and hydrology, impact on dissolved oxygen, and seasonal cycles are all part of how this organism exerts its influence on its stream and how it is also controlled by environmental features.

\section{Stalks Responsible for High Biomass}

A comparison of D. geminata biomass as ash free dry mass (AFDM) and chlorophyll a confirms that the mats are accumulations of stalks with a thin surface layer of cells (Larned and others, 2006). The AFDM biomass of $D$. geminata was measured to be 250 times greater than the chlorophyll $a$ biomass. The comparison also indicates that the ecological interactions related to $D$. 
geminata are primarily due to the impact of the extracellular stalks, not the cells themselves. Blooms of $D$. geminata generate biomass and chlorophyll $a$ values many times those found in nonbloom conditions. Furthermore, AFDM biomass is produced at a level considered indicative of a biologically impaired river. In New Zealand rivers, an analysis of AFDM and chlorophyll $a$ exceeded national guidelines for periphyton biomass (table 1) (Kilroy and others, 2005c). The guidelines are intended to maintain high quality angling and fish habitat, and values are much higher than in non-D. geminata streams in New Zealand and elsewhere.

Table 1. Minimum and maximum ash free dry mass (AFDM) and chlorophyll a (Chl. a) for periphyton cover from studies in New Zealand rivers. Sites with large masses of $D$. geminata are shown in bold text. (Data from Kilroy and others, 2005c.)

\begin{tabular}{|c|c|c|c|c|c|}
\hline River & $\begin{array}{l}\text { AFDM min } \\
\left(\mathrm{g} / \mathrm{m}^{2}\right)\end{array}$ & $\begin{array}{l}\text { AFDM max } \\
\left(\mathrm{g} / \mathrm{m}^{2}\right)\end{array}$ & $\begin{array}{c}\text { Chl. a min } \\
\left(\mathrm{mg} / \mathrm{m}^{2}\right)\end{array}$ & $\begin{array}{c}\text { Chl. a max } \\
\left(\mathrm{mg} / \mathrm{m}^{2}\right)\end{array}$ & Reference \\
\hline Mararoa & 18 & 1171 & 145 & 1029 & Kilroy and others, 2005c \\
\hline Lower & 34 & 210 & 157 & 1155 & Kilroy and others, $2005 \mathrm{c}$ \\
\hline Waiau & & & & & \\
\hline Ohau & 10 & 63 & $\sim 2$ & $\sim 55$ & Biggs and Hickey, 1994 \\
\hline $\begin{array}{l}\text { Quebec } \\
\text { streams }\end{array}$ & 2.4 & 22.6 & 5.1 & 54.6 & $\begin{array}{l}\text { Bourassa and Cattaneo, } \\
1998\end{array}$ \\
\hline Mataura & $\sim 2.5$ & 45 & - & - & Biggs and others, 1998 \\
\hline Waiau & - & - & $\sim 0.3$ & $\sim 200$ & Biggs and others, 1998 \\
\hline
\end{tabular}

\section{Nuisance Blooms}

Although $D$. geminata occurs in both lakes and flowing waters, nuisance blooms are only known in streams and rivers. In contrast to historical, episodic growths of D. geminata, nuisance blooms are masses of cells and stalks that extend for greater than $1 \mathrm{~km}$ and persist for several months of the year. During a nuisance bloom, D. geminata cells produce copious amounts of extracellular stalk material.

For the purposes of this document, the phrase "nuisance bloom" refers to growths in sites where $D$. geminata was considered within its native range (northern boreal and high elevation sites), but where benthic mats are spatially and temporally extensive (table 2). For example, nuisance blooms in Rapid Creek, S. Dak. are present over a 5 to $10 \mathrm{~km}$ reach, at 30 to 100 percent coverage, for over 4 months of the year, and are recurring. "Invasive blooms" refer to the appearance of $D$. geminata in locations with no previous record (for example, New Zealand) and denotes the behavior of an introduced non-indigenous species.

In a broad sense, nuisance algal blooms are typically directly related to anthropogenic increases in nutrient input to surface waters (Schindler, 1977; Anderson and others, 2002). Increased concentrations of nitrogen and phosphorus result in adverse effects due to excessive primary production of algae. Cyanobacterial (blue-green algae) blooms are a well-known phenomenon in freshwater with high quantities of phosphorUS (Jacoby and others, 2000; Bowling, 1994, Hecky and Kilham, 1988). In contrast, blooms of $D$. geminata are unlike other algal blooms, because they are associated with nutrient-poor waters. Notably, many D. geminata blooms have occurred in stream habitats generally considered pristine or with limited ecological disturbance (Jónssen and others 2000; Sherbot and Bothwell, 1993). 
In North America, documenting the occurrence and extent of $D$. geminata is problematic. Standard counting techniques for diatom analysis underestimate the presence of $D$. geminata in the western United States by at least 50 percent (S. Spaulding, USGS unpub. data, 2006). Compared to other diatom species, $D$. geminata has much larger cells $(80-150 \mu \mathrm{m}$ in length), yet smaller cells dominate the diatom community (fig. 10). Counting procedures intended to evaluate diatom species in the periphyton are often based on a fixed count (for example, 300 cells counted), which favor small, numerous species. An alternative technique is to note the presence of D. geminata cells,

Table 2. Listing of sites in the United States and Canada that are considered to contain nuisance blooms. Note that the list is not complete, because of difficulties in characterizing nuisance blooms.

\begin{tabular}{|c|c|c|c|}
\hline $\begin{array}{l}\text { Province/ } \\
\text { State }\end{array}$ & River & Years & Reference \\
\hline Alberta & $\begin{array}{l}\text { Deer } \\
\text { Red Bow }\end{array}$ & Late 1990's & A. Kirkwood, U. Calgary, unpublished data, 2006 \\
\hline Arkansas & $\begin{array}{l}\text { Red } \\
\text { White }\end{array}$ & 2005 & Shelby, 2006 \\
\hline California & American Fork & Mid 1990’s & $\begin{array}{l}\text { S. Spaulding, USGS, unpublished data, } 1997 \\
\text { S. Lehr, California Department of Fish and Game, } \\
\text { personal communication, } 2006\end{array}$ \\
\hline Montana & Kootenai & $2001-?$ & Holderman and Hardy 2004 \\
\hline Tennessee & $\begin{array}{l}\text { Clinch } \\
\text { South Holston }\end{array}$ & 2005 & $\begin{array}{l}\text { T. Baker, Tennessee Valley Authority, personal } \\
\text { communication, } 2006\end{array}$ \\
\hline South Dakota & Rapid Creek & 2002 & $\begin{array}{l}\text { J. Shearer, South Dakota Department of Game, } \\
\text { Fish, and Parks, personal communication, } 2006\end{array}$ \\
\hline Virginia & $\begin{array}{l}\text { Jackson } \\
\text { Smith }\end{array}$ & $\begin{array}{l}2006 \\
2006\end{array}$ & $\begin{array}{l}\text { S. Smith, Virginia Department of Game and Inland } \\
\text { Fisheries, personal communication, } 2006\end{array}$ \\
\hline
\end{tabular}

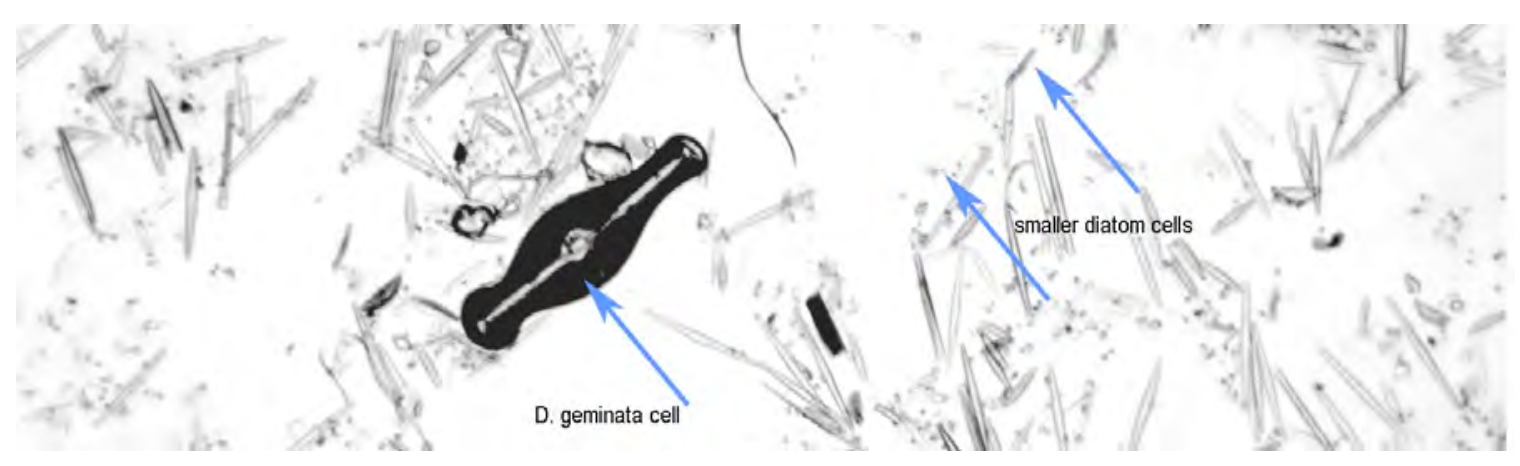

Figure 10. Microscope image of diatoms showing relative size of cells. Didymosphenia geminata is underestimated in terms of presence because standard counting techniques are directed at small species. (Image by S. Spaulding, USGS.) 
even if they do not appear in standard analysis. Interestingly, D. geminata never comprises greater than 3 percent of the diatom community in western streams (EPA Environmental Monitoring and Assessment Program (EMAP) unpublished data), even within samples collected from nuisance blooms. Reports of data using biovolume avoid part of the problem (Jónssen and others, 2000), by reporting abundance in terms of biomass rather than number of cells.

A measure such as the visual biovolume index (Kilroy and others, 2005a) is a preferred method to estimate the abundance and impact of $D$. geminata. The visual biovolume index is a measure of the percent coverage of $D$. geminata on a cross section of stream channel, multiplied by the thickness of the mat. The index takes the amount of extracellular stalk into account and is more appropriate for documenting the extent of nuisance blooms. In order to track the geographic distribution of D. geminata on a global scale, it is important to use effective and proper documentation of sites and archive voucher samples.

\section{Legacy of Stalks}

The extracellular stalk of $D$. geminata is a complex, multilayered structure, resistant to degradation in streams. Observations in Colorado streams show that stalks persist up to 2 months following a peak in growth of $D$. geminata (S. Spaulding, USGS unpub. data, 2006). In effect, the stalks persist in the stream longer than the cells that produced them (fig. 11). Furthermore, the stalks trap fine sediment within their dense matrix and change the nature of the stream substrate. This coating of the stream benthos may then act to control the algae and invertebrate species able to feed and move on those surfaces. The legacy of the D. geminata stalks is a potentially strong influence on stream community composition. It is important to evaluate the apparent resistance of the stalk to degradation by bacteria and fungi and to determine ecosystem effects of stalk material.

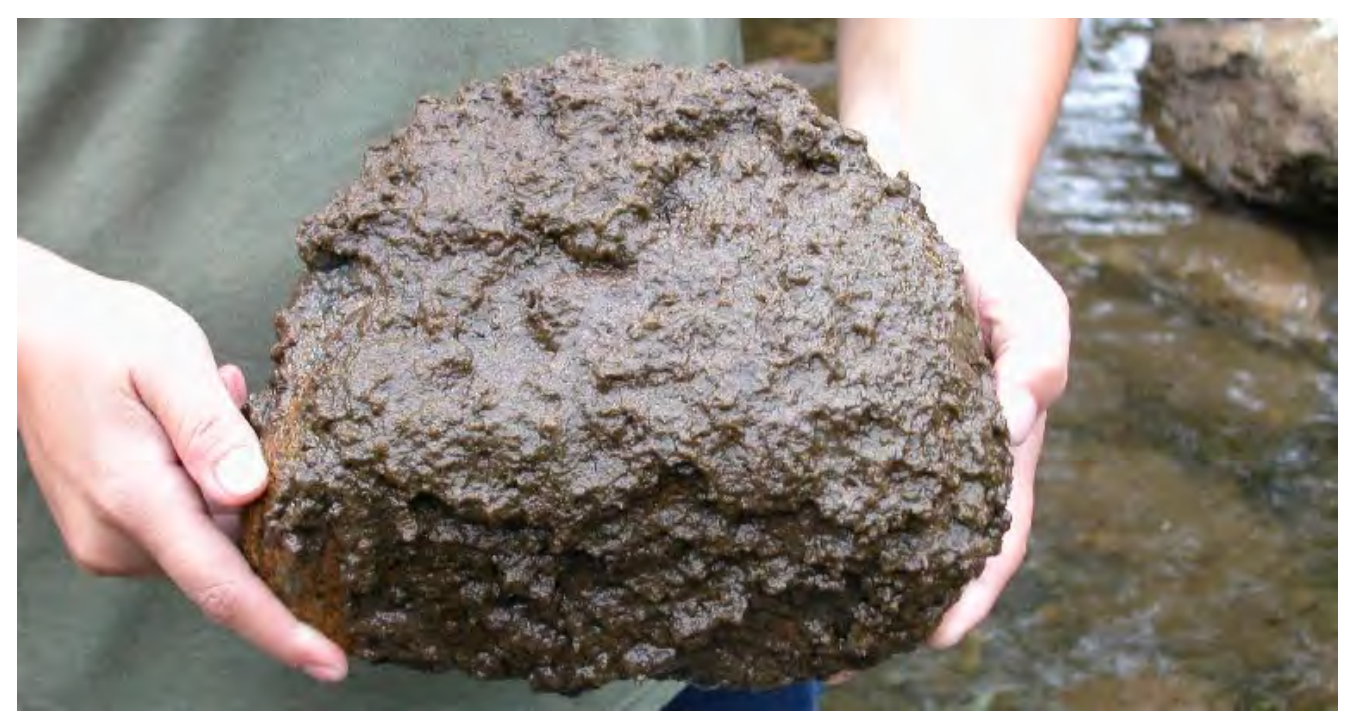

Figure 11. Image of a rock coated with $D$. geminata stalks and fine sediment. The cells of the diatom are no longer present, but the stalks continue to determine the nature of the stream substrate. (Image by S. Spaulding, USGS.) 


\section{Interactions with Invertebrates}

Abundance and diversity of benthic macroinvertebrates are likely to be affected by $D$. geminata in two ways: direct trophic interactions and habitat interactions (Larned and others, 2006). Direct trophic interaction refers to utilization of $D$. geminata as a food source. Macroinvertebrate species that consume $D$. geminata are expected to be favored over those species that do not eat $D$. geminata. Habitat interaction refers to utilization of substrates by macroinvertebrates. Species that require exposed sediment are expected to be negatively impacted by extensive coverage of $D$. geminata. Results from New Zealand rivers indicate that both number of species and density of invertebrates were greater with higher $D$. geminata coverage. However, few of the species present were characteristic of high river health. At low levels of $D$. geminata abundance, invertebrate abundance and diversity increased.

These initial results suggest that the impact of $D$. geminata on aquatic macroinvertebrates is directly related to temporal and spatial extent of nuisance blooms. If $D$. geminata masses are capable of altering the taxonomic composition and size of benthic macroinvertebrates present in the drift, that relationship represents a trophic level impact. Further work should resolve the differences in impacts of D. geminata at both high and low densities and determine whether there are threshold levels of nuisance growths. In addition, it would be beneficial to determine the extent to which macroinvertebrate grazing reduces $D$. geminata abundance. An open question is the degree to which macroinvertebrates are physically able to move through the masses of stalks to gain access to the nutritious cells.

\section{Interactions with Fish}

Studies on the effects of D. geminata on native New Zealand fish are in progress (Larned and others, 2006). Given large amounts of non-nutritious stalk material present on stream substrates in affected areas, D. geminata is predicted to have deleterious effects on native fish. Fish that inhabit benthic habitats, consume benthic prey, and nest beneath or between cobbles are expected to be the most impacted because they utilize the same habitat as D. geminata (Larned and others, 2006). Nuisance growths of $D$. geminata have the potential to impact fisheries through food web interactions with aquatic macroinvertebrates. That is, if the favored food sources for fish are impacted in a negative way, fish will also be impacted negatively.

\section{Water Chemistry}

Water chemistry is typically considered a controlling factor for diatom distribution and abundance, particularly nutrient concentrations and $\mathrm{pH}$. Historically, D. geminata was considered to be restricted to oligotrophic (low nutrient) and low temperature waters and to have a broad range of conductance in the European Alps (Krammer and Lange-Bertalot, 1986). Although historical values of chemical and physical parameters in relation to D. geminata biomass were not recorded, there is a widespread understanding among diatomists and aquatic ecologists that $D$. geminata had narrow environmental tolerances. Therefore, one of the commonly noted observations about this diatom is the expansion of its ecological tolerance to a broader physical and chemical range (Kawecka and Sanecki, 2003; Kilroy, 2004).

Preliminary data from a random survey of streams in the western United States (Stoddard and others, 2005) show that D. geminata is present in a wide range of freshwater conditions (fig. 12). These data are presented based on presence/absence of D. geminata in the western EMAP study. Rather than being restricted to cold temperatures, D. geminata is present in waters from 4 to 

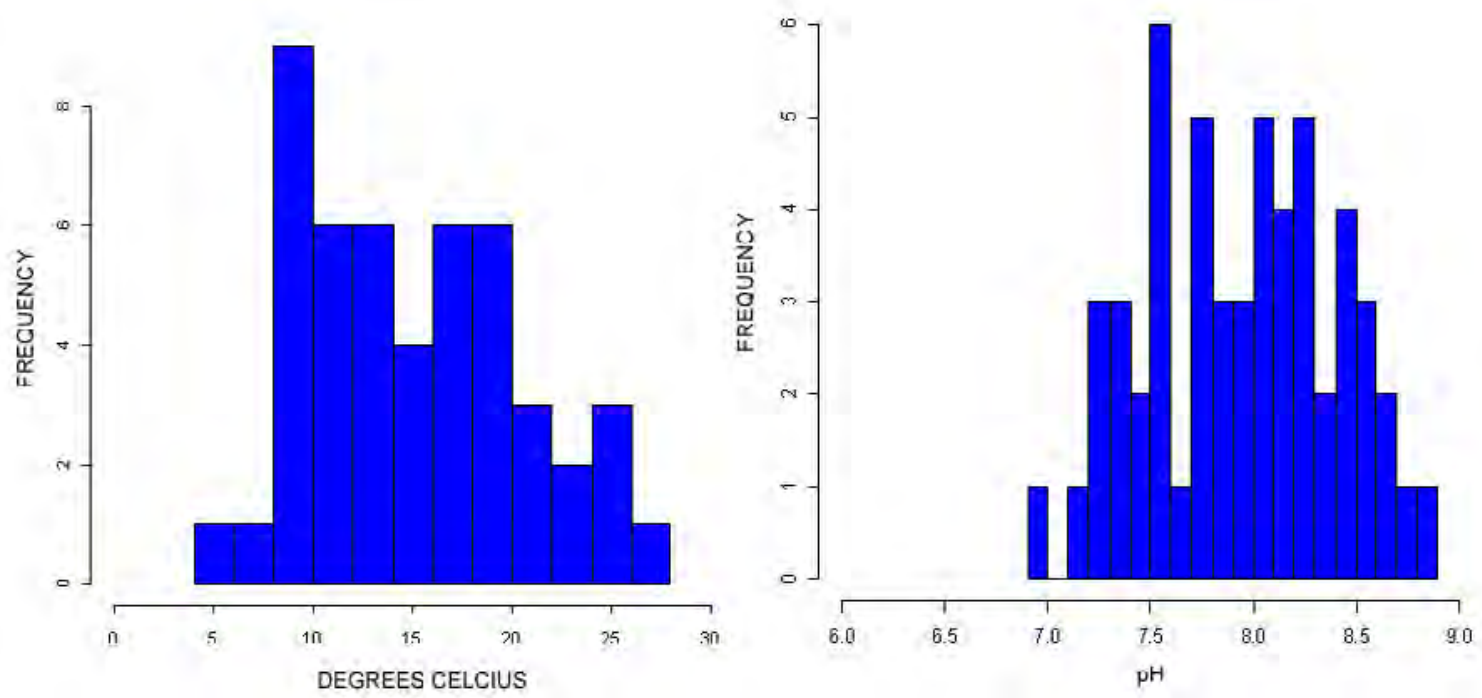

Figure 12. $A$, Water temperature versus frequency of sites with $D$. geminata present in western streams of the United States. B, pH versus frequency of sites with D. geminata present. (Unpublished data from EPA EMAP study, 2000-2003.)

$27^{\circ} \mathrm{C}$, and shows a temperature range greater than what was previously observed. The relation of $\mathrm{D}$. geminata presence to $\mathrm{pH}$ is more narrow, with $\mathrm{D}$. geminata found in waters at or above a $\mathrm{pH}$ of 7 .

The ranges of specific conductance and acid neutralizing capacity (ANC) at sites with $D$. geminata present are both broad (fig. 13). These data demonstrate a wide range of tolerance, from electrolyte-poor to concentrated waters, although $D$. geminata occurs more often at lower values of conductance and ANC.

Although $D$. geminata occurs most frequently in waters with low total phosphorus $(<2 \mu \mathrm{g} / \mathrm{l})$ and low nitrate $(<1 \mathrm{mg} / \mathrm{L})$ (fig. 14), it can also be found where both of these nutrients are present at very high concentrations. These values show where $D$. geminata is present, but give no indication of the biomass or growth rate in association with nutrient concentration. Furthermore, it is unknown if $D$. geminata is limited by either of these important nutrients in any streams in North America. In New Zealand, nutrient enrichment experiments indicate that growth of $D$. geminata is limited by nitrogen, phosphorus, or both nutrients within most of its current range (Larned and others, 2006). In other words, with greater concentrations of either nutrient, growth would be stimulated. Increased loading of nutrients to affected rivers by watershed sources is expected to result in increased growth of $D$. geminata.

\section{Hydraulic Range}

Didymosphenia geminata thrives in a wide range of hydraulic conditions (fig. 15) (Kilroy and others, 2005d). The hydraulic range is striking, because dense mats of the alga are able to grow in slow moving, shallow waters as well as in waters with greater depth and velocity than could be safely measured by technicians. In the Mararoa and Waiau Rivers, masses of $D$. geminata were greatest at water velocities of approximately $0.5 \mathrm{~m} / \mathrm{s}$. With stable flow, biomass of $D$. geminata tends to increase. In fact, the best hydrological predictor of $D$. geminata biomass is number of days 

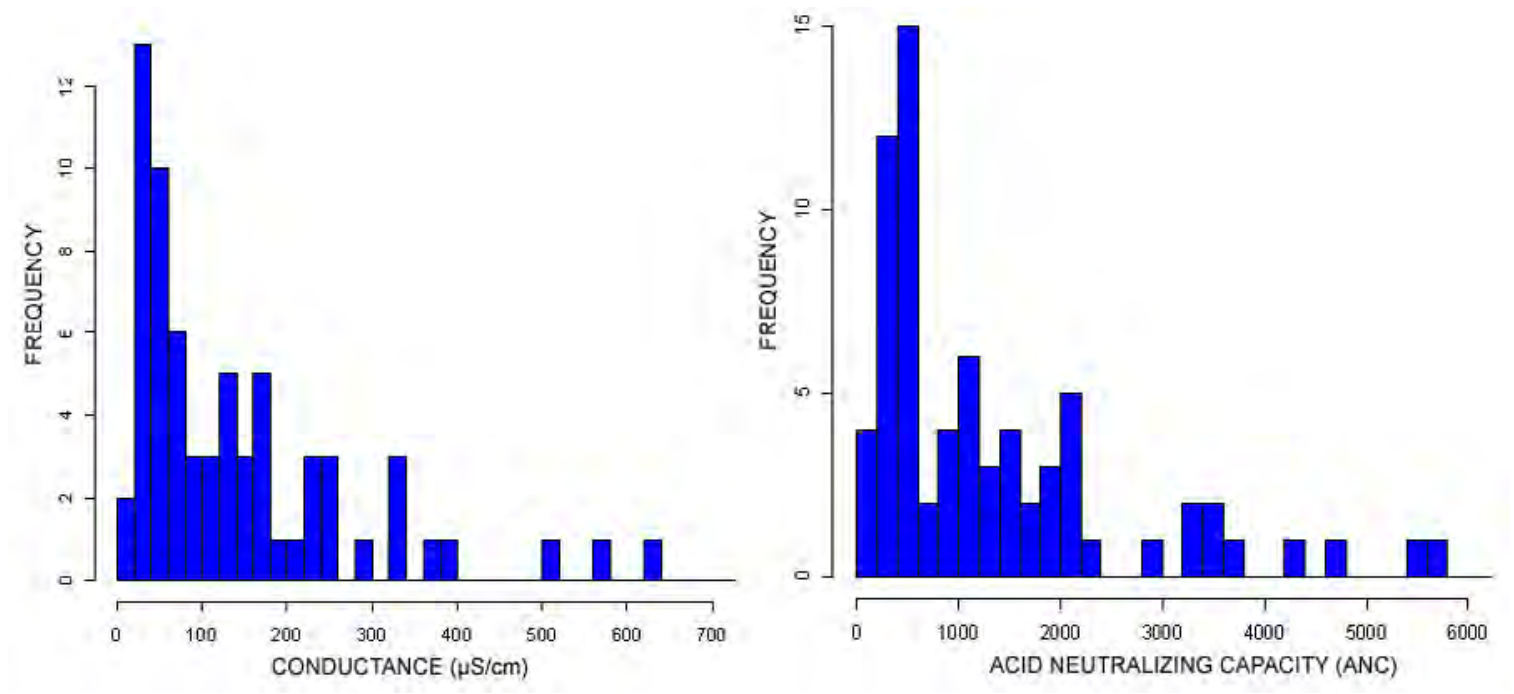

Figure 13. $A$, Conductance $(\mu \mathrm{mho} / \mathrm{cm})$ versus frequency of sites with $D$. geminata present in western streams of the United States. $B$, Acid neutralizing capacity (ANC) versus frequency of sites with $D$. geminata present. (Unpublished data from EPA EMAP study, 2000-2003.)
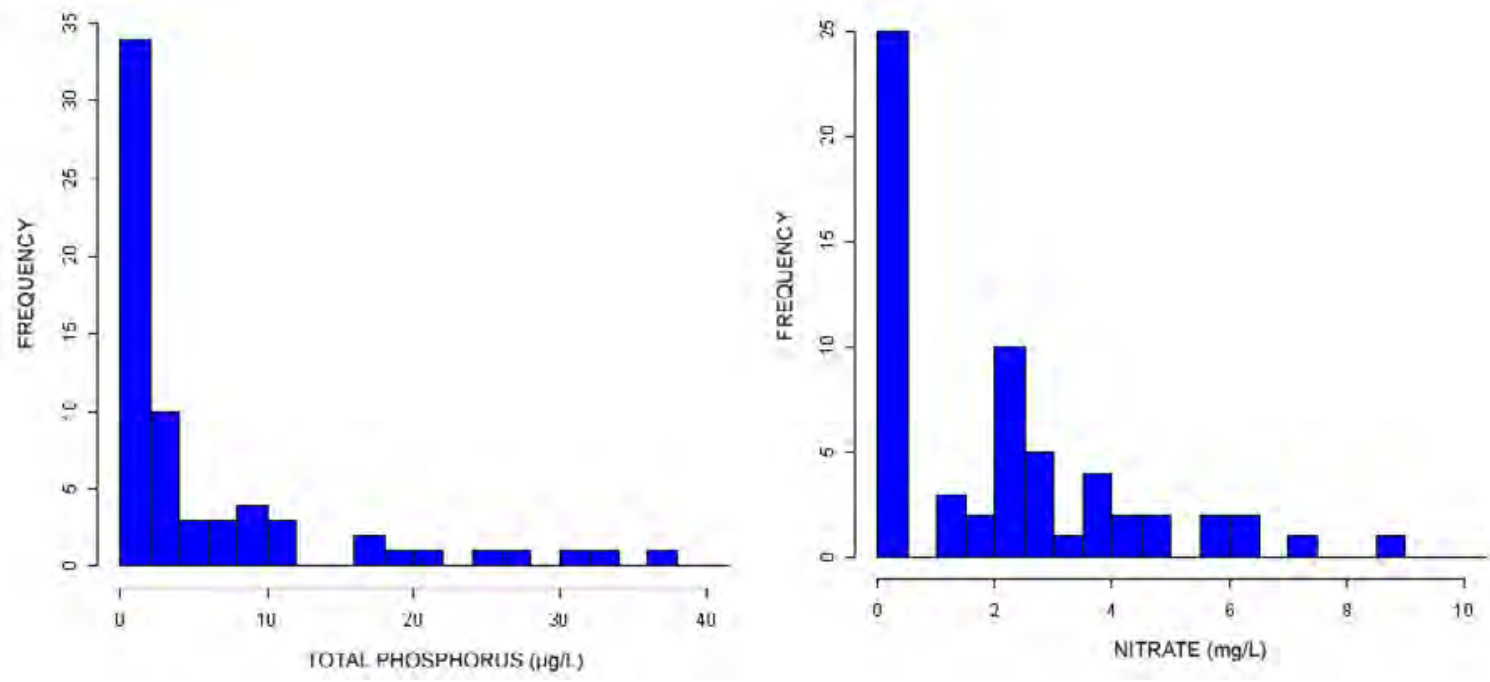

Figure 14. $A$, Total phosphorus ( $\mu \mathrm{g} / \mathrm{L}$ ) versus frequency of sites with $D$. geminata present in western streams of the United States. $B$, Nitrate $(\mathrm{mg} / \mathrm{L})$ versus frequency of sites with $D$. geminata present. (Unpublished data from EPA EMAP study, 2000-2003.) 


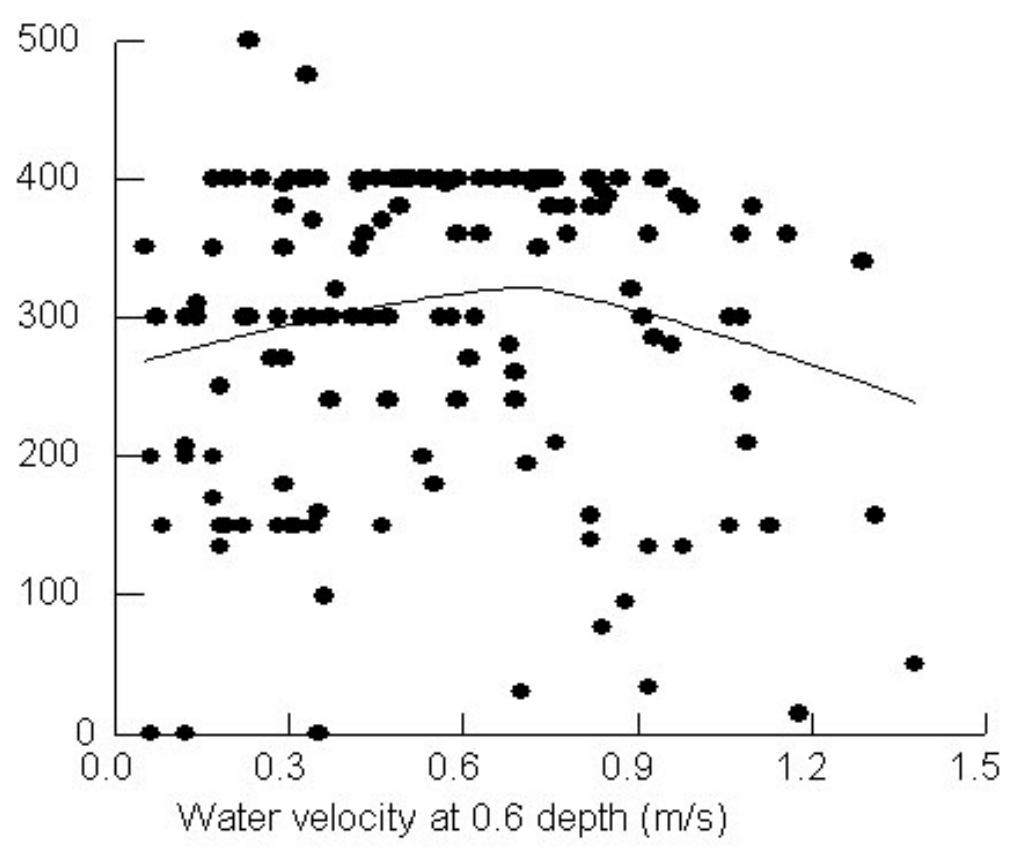

Figure 15. Water velocity versus visual biovolume index in the Mararoa River, New Zealand. The pattern indicates there is no relation between water velocity and visual biovolume index. In other words, D. geminata forms dense mats (high visual biovolume index) from low to high water velocities. (Data from Kilroy and others, 2005c.)

since a flood greater than 75 to $100 \mathrm{~m}^{3} / \mathrm{s}$. In other words, large floods scour the river bed and return biomass to a low level. However, in order to reduce cell biomass, floods must be high enough to cause the rocks on the streambed to mobilize (Larned and others, 2006), scouring the cells from rock surfaces.

In North America and Europe, high density blooms are frequent in rivers directly below impoundments (Skulberg, 1982; Dufford and others, 1987; Kawecka and Sanecki, 2003). A monthly survey of rivers in Alberta, Canada, suggests that $D$. geminata occurs with higher frequency in locations where flow and temperature is regulated by dams compared with nonregulated rivers (A. Kirkwood, University of Calgary, personal commun., 2006). In these river reaches, stable flows and fairly constant temperatures favor development of large masses of $D$. geminata. Restoration of historic, or pre-impoundment, natural flows in rivers may mitigate nuisance blooms, as well as restore river condition.

\section{A Biological Paradox}

Recent work on $D$. geminata blooms has resulted in a remarkable observation. Within the masses of extracellular stalks and cells, concentrations of dissolved oxygen are supersaturated with respect to the atmosphere (Larned and others, 2006). Determining the source of nutrients and flux of oxygen within the algal mats is likely to reveal how $D$. geminata attains its remarkable biomass. Typically, the concentration of dissolved oxygen within algal mats formed by other species is not supersaturated, but oxygen concentrations may be quite low as cells respire and decompose. In contrast, peak values of dissolved oxygen are present well below the surface of the $D$. geminata 
mats. Larned and others propose that these algal mats contain other photosynthetic organisms that are actively producing oxygen. They suggest that a unique assemblage of organisms is able to utilize high concentrations of dissolved nutrients produced in organic matter at the bases of mats, and then can transfer these nutrients to D. geminata cells. An investigation of the processes within the mat matrix will help to address the biological paradox of how $D$. geminata produces excessive biomass in low nutrient streams and rivers, over short periods of time.

\section{Molecular Markers}

Craig Cary (University of Waikato, New Zealand) is leading an effort to elucidate a molecular marker that allows a quick, inexpensive, and reliable method for determining the presence of $D$. geminata within a watershed. The Cary lab has already been successful in determining DNA sequences unique to D. geminata, and the method is promising for monitoring efforts (Cary and others, 2006). Following this work, the expanding distribution of $D$. geminata has prompted a genetic survey to determine:

1. How genetically related are populations of $D$. geminata around the world?

2. Are there one, or more, "source" populations that are able to spread to new sites?

3. Has there been a genetic change in one or more populations that has led to invasive behavior?

In spring of 2006, Cary initiated a broad request to the scientific and management community to contribute samples of $D$. geminata for a global population study. Samples have been contributed from the broadest distribution possible, including but not limited to, representative samples from Asia, Europe, and North America.

\section{Range Expansion}

The mechanisms for D. geminata to expand its range to new watersheds are not well understood. Early suggestions that increases in UV-B radiation was tied to the expansion were not supported (Sherbot and Bothwell, 1993; Wellnitz and others, 1996; Rader and Belish, 1997). Recent work illustrates the capacity of $D$. geminata to survive outside of the stream environment as well as potential vectors in its spread. Cells are able to survive and remain viable in cool, damp, dark conditions for at least 40 days (Kilroy, 2005). Fishing equipment, boot tops, neoprene waders, and felt-soles in particular (fig. 16), all provide a site where cells remain viable, at least during short-term studies (Kilroy and others, 2006). At the same time, prime destinations for fly fishing are becoming more popular with anglers. Rather than frequent a favorite local fishing site, it is now common that anglers travel to multiple or distant destinations for fly fishing vacations (fig. 17). Moreover, they may be casting flies in a river less than $24 \mathrm{hrs}$ after leaving their local rivers in North America, unknowingly spreading $D$. geminata.

For aquatic organisms, the relationship between the spread of invasive species to recreation is well established (for example, Eurasian water milfoil (Myriophyllum spicatum L.) and zebra mussels (Dreissena polymorpha); see Madsen and others, 1988; Strayer and others 1996; Vitousek and others, 1997; Schneider and others, 1998; Johnson and others, 2001). Gear and equipment used in aquatic recreation is being tested for its role in spreading $D$. geminata, but it is possible that humans transport $D$. geminata in other ways (for example, boats including jet skis, water transport for rural fire fighting; irrigation; water diversions; waterfowl hunting; and float airplanes). Determining the likely risk of such vectors may be valuable for targeting control programs and public messages about decontamination. 


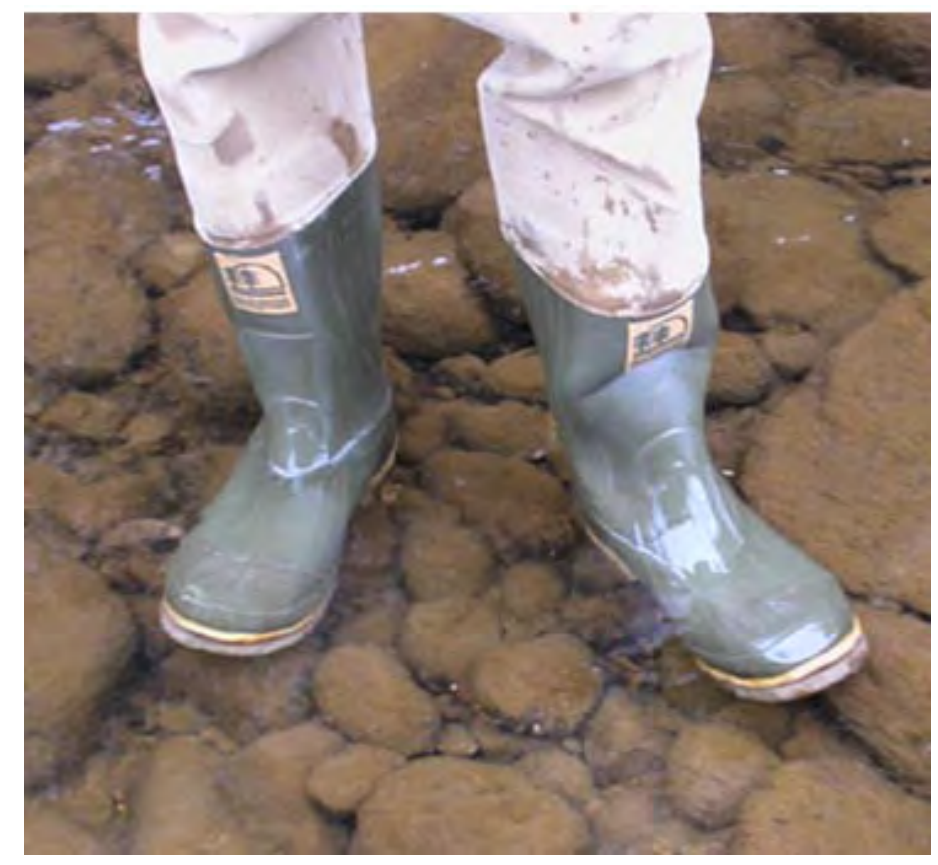

Figure 16. D. geminata is able to survive on boot tops, neoprene waders, and feltsoles and may be spread to distant sites. (Image by Sarah Spaulding, USGS.)

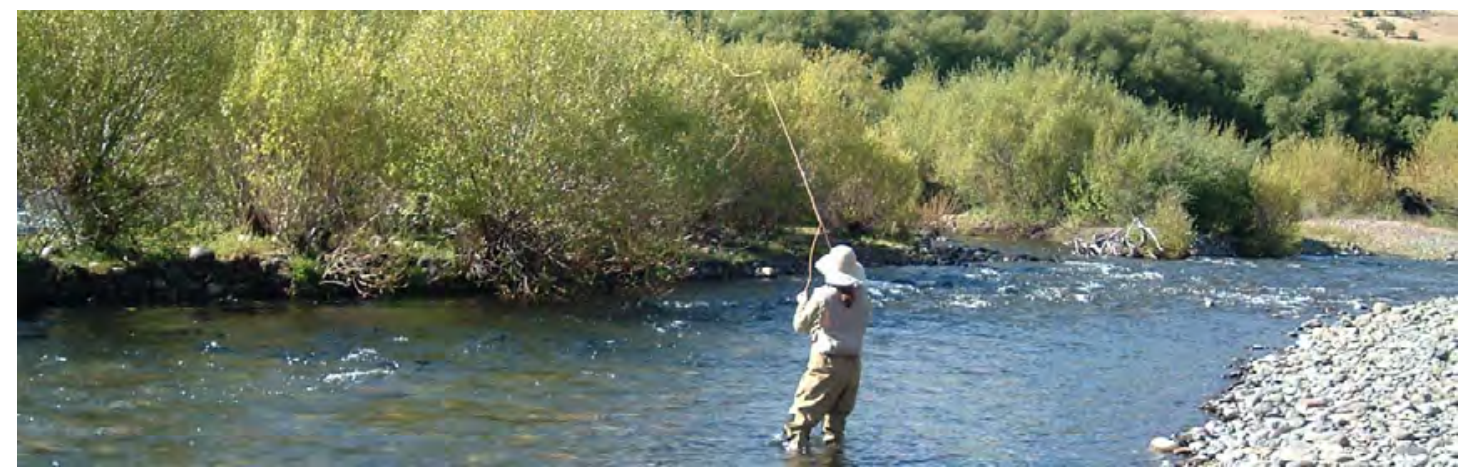

Figure 17. An increasing number of anglers from North America are visiting other continents to fish, as illustrated by this tourist in Rio Malleo, Argentina. Ecological models predict that rivers in South America and Australia contain suitable habitat for D. geminata. (Image by Mat Wilhelm, Federation of Fly Fishers).

\section{Economic Impact}

While D. geminata is not considered invasive in the United States, the diatom's nuisance blooms have economic impacts. The human population of the western United States is closely dependent on a system of canals to transport water for hydropower generation, agriculture, and human consumption. Nuisance algae, including $D$. geminata, regularly thrive on the stable substrate and flow regime of canal systems (Pryfogle and others, 1997). In some canal systems, 
managers implement regular removals by scraping $D$. geminata growths from the concrete surfaces of canals (fig. 18).

Didymosphenia geminata is often reported by recreationalists to land managers as being unsightly. The stalks are frequently mistaken for raw sewage, leading homeowners and recreationalists to complain to local water treatment plants. Many communities rely on tourism dollars that are generated by outdoor recreation. Natural resource opportunities represent important economic value, yet they may be vulnerable to damage by the spread of nuisance species. In the United States, the cost to control and eradicate nuisance and invasive species is estimated at $\$ 120$ billion annually, with $\$ 1$ billion from the impacts of zebra mussels alone (Pimentel and others, 2005).

Upon the appearance of D. geminata in New Zealand in October 2004, Biosecurity New Zealand initiated a national incursion response based on the potential losses to the national economy. The presence of D. geminata threatens the opportunities for tourists to experience clear, unimpacted rivers. Commercial eel fisheries, water supplies, tourism, and biodiversity values are projected to be impacted and economic losses are estimated at between \$NZ 57 and 285 million over a period of 8 yrs (Branson, 2006).

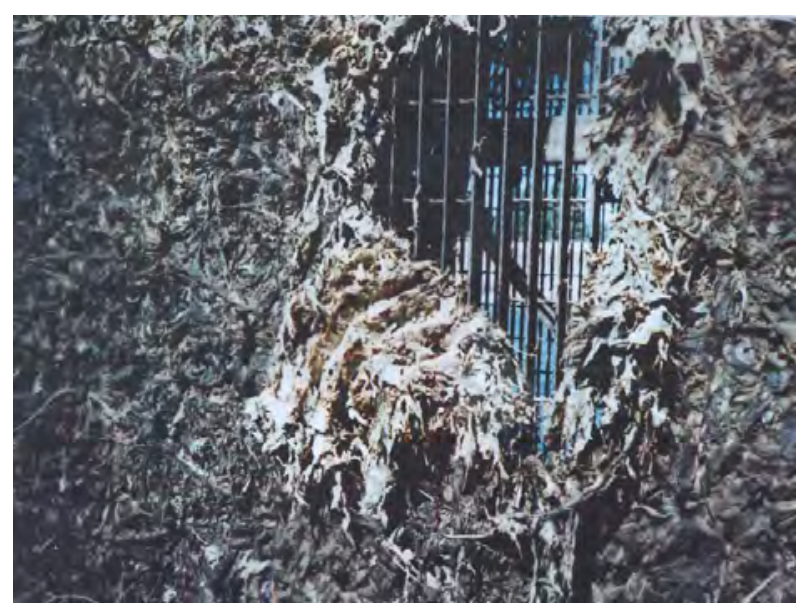

Figure 18. Stalks of D. geminata clog a grate in a water supply canal in California. (Image by Peter Pryfogle, Idaho National Laboratory.)

\section{Control Techniques}

Biosecurity New Zealand is currently pursuing a series of experimental trials to test biocides for potential control of D. geminata within streams and rivers in New Zealand (Jellyman and others, 2006). In order to test the efficacy of various biocides, D. geminata was grown on artificial substrates and placed in experimental stream channels. Several biocides were tested on D. geminata. The mats were exposed to each biocide for a period of $1 \mathrm{hr}$ and the viability of algal cells determined at various time periods, up to 28 days after treatment. Mortality of fish in the experimental stream channels was also assessed. Of the five biocides tested, chelated copper had the greatest negative effect on $D$. geminata for all contact times. In the next stages, the tolerance limits of fish to chelated copper will be established. Although copper compounds have a long history of use as algaecides the United States- in lakes, reservoirs, and to a lesser extent, flowing waters-they have not been evaluated for control of D. geminata outside of New Zealand. 


\section{Reduce the Spread}

Plants, animals, and microscopic organisms, including D. geminata, may adhere to waders, boots, boats, float tubes, and angling gear. Cleaning gear before traveling between bodies of water, whether between nearby streams or to international destinations, is crucial. Decontamination of gear is the only way to prevent the spread and subsequent introduction of D. geminata into new watersheds. While decontamination will not destroy all invasive species, cleaning procedures minimize the possibility of spread. These simple treatments effectively destroy D. geminata algal cells (fig. 19) (Kilroy, 2005):

An aggressive education and outreach program could be implemented to change water resource user behavior in order to minimize spread of $D$. geminata on a global scale. A public awareness campaign, directed at freshwater anglers, boaters, professional guides, and other recreationalists could be integrated with existing invasive species programs. Freshwater resource users, including ecologists, water managers, fisheries biologists, and other scientists, need to be aware of the threat and practice decontamination procedures to prevent the spread. Furthermore, members of the United States Aquatic Nuisance Species (ANS) Task Force could be informed of the distribution and impact of $D$. geminata, and include this organism within the scope of nuisance and invasive species within the United States.

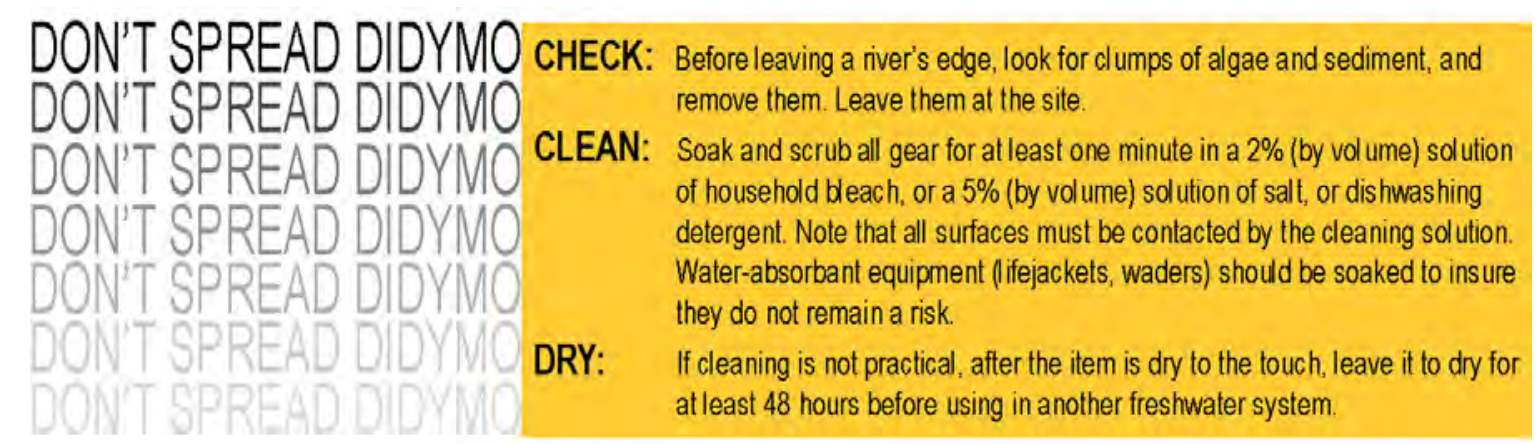

Figure 19. Methods to prevent spread of $D$. geminata. (Graphic from U.S. EPA information sheet.)

\section{Summary}

Didymosphenia geminata now has a broad distribution in North America, a condition that appears to have developed in the past 10 to $20 \mathrm{yrs}$. Although the diatom is more common in the western United States, it is also forming large growths in rivers in the eastern United States and Canada. This diatom was known to produce large masses since the earliest historical records, but now the blooms are over a greater area in the Northern Hemisphere and spreading across rivers in the Southern Hemisphere While D. geminata was formerly considered to have narrow ecological tolerances, it is now present in streams exhibiting a wide range of chemical characteristics. It is capable of growing throughout most of the year in streams with low to high $\mathrm{NO}_{3}$ concentrations $(<1 \mathrm{mg} / \mathrm{L}$ to $>8 \mathrm{mg} / \mathrm{L})$, low to high temperatures $\left(4-27^{\circ} \mathrm{C}\right)$, and within a broad range of light exposure. The diatom forms an unknown number of nuisance blooms in North America, covering benthic surfaces for greater stream reaches than 1 to $2 \mathrm{~km}$. The diatom is invasive in New Zealand and is rapidly expanding to new watersheds, despite aggressive control measures. 
Didymosphenia geminata causes us to question our fundamental understanding of streams and rivers. First, $D$. geminata presents a biological paradox: how is excessive biomass produced in low nutrient streams and rivers, over short periods of time? Second, D. geminata produces a

mucopolysaccaride stalk that appears to be resistant to biodegradation by bacteria and fungi. What is the unique composition and structure of the stalk, and how does the stalk itself play a role in the success of this organism? Third, D. geminata has direct and indirect impacts across aquatic trophic levels. What is the long-term significance of stalks that are resistant to decomposition and trap fine sediment past the life span of the organism? Fourth, there are suggestions that macroinvertebrates and fish respond to nuisance levels of $D$. geminata with community and population level shifts in composition, abundance, and size class. What are the trophic impacts of $D$. geminata? Finally, is there a genetically-based physiological change in this organism that is linked to a nuisance strain?

Molecular markers present the opportunity to trace the genetic relationships of nuisance outbreaks, and those records can be compared with models of predicted global distribution.

Scientists, conservationists, and natural resources managers are concerned about nuisance blooms of $D$. geminata and change in behavior of this organism or appearance of a nuisance strain. As an outcome of the International Didymosphenia Symposium in Bozeman, Mont., two goals are clear:

Goal 1) Develop an outreach effort to inform and involve the public and government agencies.

Goal 2) Develop an approach to research that will allow us to address the behavior and impacts of this organism.

This document and the following alternative responses are intended to accomplish these goals.

\section{Potential Actions}

\section{Responses to satisfy Goal 1}

- An education and outreach program may change water resource user behavior and minimize spread of $D$. geminata on a global scale.

- A public awareness campaign, directed at freshwater anglers, boaters, professional guides, and other recreationalists, could be integrated with existing invasive species programs.

- Freshwater resource users, including ecologists, water managers, fisheries biologists, and other scientists, could be more aware of the threat and practice decontamination procedures to prevent the spread.

- Members of the United States Aquatic Nuisance Species (ANS) Task Force could be informed of the distribution and impact of D. geminata and include this organism within the scope of nuisance and invasive species within the United States.

- Rivers in the Southern Hemisphere are particularly at risk to new introduction and invasion. Appropriate agency personnel in Australia, Argentina, Chile, and Peru could be notified and made aware of the potential ecological damage and urgency of implementing decontamination procedures.

\section{Responses to satisfy Goal 2}

- Determine if there has been a genetically based physiological change in this organism linked to a nuisance strain. Molecular markers provide an opportunity to trace the relationships of 
- Determine the degree to which the spread of $D$. geminata is aided by specific human vectors, such as felt-soled waders, or other plausible mechanisms.

- Track the geographic distribution of D. geminata on a global scale using effective and proper documentation of sites and voucher samples.

- Determine the ecological conditions under which excessive biomass is produced in low nutrient streams and rivers, over short periods of time. Develop strategies to mitigate existing blooms.

- Determine the unique composition, structure, and cellular processes that produce the $D$. geminata stalk, which is responsible for its negative ecosystem impacts.

- Evaluate the apparent resistance of the stalk to degradation by bacteria and fungi, and determine ecosystem effects of stalk material.

- Investigate the contribution that D. geminata makes to nutrition of macroinvertebrates. Are macroinvertebrates able to access the cells from within the mass of stalks?

- Resolve the extent to which macroinvertebrate grazing can reduce $D$. geminata abundance.

- Determine the direct and indirect impacts of D. geminata and its stalks to aquatic macroinvertebrates and fish. Resolve the impacts of $D$. geminata at both high and low densities and whether there are threshold levels of nuisance growths. Testing the following hypotheses could clarify the potential impacts:

- The impact of $D$. geminata on aquatic macroinvertebrates is directly related to temporal and spatial extent of nuisance blooms.

- D. geminata masses alter the taxonomic composition and size of benthic macroinvertebrates present in the drift.

- The presence of D. geminata alters the energetics of fish through altering the macroinvertebrates present in drift.

- The reduction in food energy reduces the growth rate of trout and favors small individuals over large individuals. 


\section{References Cited}

Anderson, D.M., Gilbert, P.M. and Burkholder, J.M., 2002, Harmful algal blooms and eutrophication-Nutrient sources, composition, and consequences: Estuaries, v. 25, p. 704-726.

Antoine, S.E. and Benson-Evans, K., 1983, Polymorphism and size variation in Didymosphenia geminata from Great Britain: British Phycological Journal, v. 18, p. 199-200.

Bahls, L., 2004, Northwest Diatoms: a photographic catalogue of species in the Montana Diatom Collection, with ecological optima, associates, and distribution records for the nine northwestern United States ( v. 1): Helena, Mont., L. Bahls.

Biggs, B.J.F. and Hickey, C.W., 1994, Periphyton responses to a hydraulic-gradient in a regulated river in New Zealand. Freshwater Biology, v. 32, p. 49-59.

Biggs, B.J.F., Goring, D.G. and Nikora, V.I., 1998, Subsidy and stress responses of stream periphyton to gradients in water velocity as a function of community growth form. Journal of Phycology, v. 34, p. 598-607.

Biggs, B. Spigel, B., Sutherland, D. and Kilroy, C., 2005, Preventing possible Didymosphenia transport into Lake Manapouri-estimated flow limits for the Waiau Arm and Mararoa River: New Zealand, National Institute of Water and Atmospheric Research, Client Report CHC2005110, NIWA Project MEL05516.

Bourassa, N. and Cattaneo, A., 1998, Control of periphyton biomass in Laurentian streams (Quebec): Journal of the North American Benthological Society, v. 17, p. 420_429.

Bowling, L., 1994, Occurrence and possible causes of a severe cyanobacterial bloom in Lake Cargelligo, New South Wales: Australian Journal of Marine and Freshwater Research, v. 45, p. 737-745.

Branson, J., 2006, Didymosphenia geminata economic impact assessment: Wellington, New Zealand, New Zealand Institute of Economic Research Report, p. 1-22.

Bukhtiyarova, L.N., 1999, Classification of diatom algocoenoses as a useful tool in river biomonitoring. In: Whitton, B.A., Prygiel, J., and Bukowska, J., eds., Use of algae for monitoring rivers III. Agence de 1'Eau Artois-Picardie. p. 114-121.

Campbell, M.L., 2005, Organism impact assessment (OIA) for potential impacts of Didymosphenia geminata: Blairgowrie, Victoria, Australia, All Oceans Ecology, p. 1-92.

Cary, C., Hicks, B.J., Crawford, N.J. and Coyne, K., 2006, A culture-independent approach to develop a sensitive genetic-based detection capability for Didymosphenia geminata: Client report prepared for MAF Biosecurity New Zealand. CBER Contract Report No. 45. 
Cleve, P.T., 1894-1896, Synopsis of the naviculoid diatoms: Stockholm, Kongliga Sevenska Vetenskaps-Akademiens Handlingar, Stockholm. (Reprinted 1965, Amsterdam, A. Asher and Co.)

Dawson, P.A., 1973a, The morphology of the siliceous components of Didymosphenia geminata (Lyngb.) M. Schm.: British Phycological Journal, v. 8, p. 65-78.

Dawson, P.A., 1973b, Further observations on the genus Didymosphenia M. Schmidt-D. siberica (Grun.) M. Schm.: British Phycological Journal, v. 8, p. 197-201

Dufford, R.G., Zimmerman, H.J., Cline, L.D., and Ward, J.V., 1987, Responses of epilithic algae to regulation of Rocky Mountain streams, In: Craig, J.F. and Kemper, J.B., eds., Regulated streams: advances in ecology: New York, Plenum Press, p. 383-390.

Edlund, M.B., and Stoermer, E.F., 1997, Review. Ecological, evolutionary, and systematic significance of diatom life histories: Journal of Phycology, v. 33, p. 897-918.

Hara, H., and Sahin, B., 2000, Epipelic and epilithic algae of Degirmendere River (TrabzonTurkey): Turkish Journal of Botany, v. 25, p. 177-186.

Hecky, P.E., and Kilham, P., 1988, Nutrient limitation of phytoplankton in freshwater and marine environments: A review of recent evidence on the effects of enrichment: Limnology and Oceanography, v. 33, p. 796-822.

Holderman, C.E., and Hardy, R., 2004, Kootenai River Ecosystem Project-An ecosystem approach to evaluate and rehabilitate a degraded, large riverine ecosystem. Final Report to Bonneville Power Administration, Portland OR. Project No. 1994-049-00, Contract No. 00004029.

Hynes, H.B.N., 1975, The stream and its valley, in Verhandlunge [Proceedings], Internationale Vereinigung für theoretische und angewandte Limnologie, v. 19, p. 1-15.

Jacoby, J.M., Collier, D.C., Welch, E.B., Hardy, F.J. and Crayton, M., 2000, Environmental factors associated with a toxic bloom of Mycrocystis aeruginosa: Canadian Journal of Fisheries and Aquatic Sciences, v. 57, p. 231-240.

Jellyman, P.G., Clearwater, S.J., Biggs, B.J.F., Blair, N., Bremner, D.C., Clayton, J.S., Davey, A., Gretz, M.R., Hickey, C., and Kilroy, C., 2006, Didymosphenia geminata experimental control trials (product screening and testing) and stalk degradation studies: National Institute of Water And Atmospheric Research, New Zealand, Client Report CHC2006-128, NIWA Project MAF06504.

Johnson, L.E., Ricciardi, A. and Carlton, J.T., 2001, Overland dispersal of aquatic invasive species: A risk assessment of transient recreational boating: Ecological Applications, v. 11, p.1789-1799. 
Jónssen, G.S., Jónssen, I.R., Bjornsson, M., and Einarsson, S.M., 2000, using regionalisation in mapping the distribution of the diatom species Didymosphenia geminata (Lyngbya) M. Schmidt in Icelandic rivers, in Verhandlunge [Proceedings], Internationale Vereinigung für theoretische und angewandte Limnologie, v. 27, p. 340-343.

Kara, H. and Şahin, B., 2001, Epipelic and epilithic algae of the Değirmendere River (TrabazonTurkey): Turkish Journal of Botany, v. 25, p. 177-186.

Kawecka, B., and Sanecki, J., 2003, Didymosphenia geminata in running waters of southern Poland-symptoms of change in water quality?: Hydrobiologia, v. 495, p. 193-201.

Kilroy, C., 2004, A new alien diatom, Didymosphenia geminata (Lyngbye) Schmidtits biology, distribution, effects and potential risks for New Zealand fresh waters:

National Institute of Water and Atmospheric Research, New Zealand, Client Report, CHC2004128.

Kilroy, C., 2005, Tests to determine the effectiveness of methods for decontaminating materials that have been in contact with Didymosphenia geminata: National Institute of Water and Atmospheric Research, New Zealand, Client Report, CHC2005-005, NIWA Project MAF05501.

Kilroy, C., Biggs, B., Blair, N., Lambert, P., Jarvie, B., Dey, K., Robinson, K., and Smale, D., 2005a, Ecological studies of Didymosphenia geminata: National Institute of Water and Atmospheric Research, New Zealand, Client Report CHC2005-123, NIWA Project: MAF05505.

Kilroy, C, Jarvie, B. and Sutherland, S., 2005b, Nuisance growths of periphyton in the lower Waiau River in relation to flow_A summer monitoring programme with a focus on Didymosphenia geminata: National Institute of Water and Atmospheric Research, New Zealand, Consultancy report $\mathrm{CHC} 05-59,51 \mathrm{p}$.

Kilroy, C., Lambert, P., Robinson, K. and Blair, N., 2005c, Periphyton and invertebrate monitoring programme, lower Waiau River: Results of the 2005 survey and a commentary on the ecological effects of Didymosphenia geminata. National Institute of Water and Atmospheric Research, New Zealand, Consultancy Report 2005-032.

Kilroy, C., Snelder, T., and Sykes, J., 2005d, Likely environments in which the nonindigenous freshwater diatom can survive, in New Zealand: National Institute of Water and Atmospheric Research, New Zealand, Consultancy Report 2005-043, 34 p.

Kilroy, C., Lagerstedt, A., Davey, A., Robinson, K., 2006, Studies on the survivability of the exotic, invasive diatom Didymosphenia geminata under a range of environmental and chemical conditions: National Institute of Water and Atmospheric Research, New Zealand, Client Report CHC2006-116, NIWA Project MAF06506.

Kociolek, J.P., and Stoermer, E.F., 1993, Freshwater gomphonemoid diatom phylogenyPreliminary results: Hydrobiologia, v. 269-270, p. 31-38. 
Krammer, K., and Lange-Bertalot, H., 1986, Süsswasserflora von Mitteleuropa.. Bacilllariophyceae. (v.2). Naviculaceae (pt.1) Jena, Germany, Fisher, 876 p.

Larned, S., Biggs, B., Blair, N., Burns, C., Jarvie, B., Jellyman, D., Kilroy, C., Leathwick, J., Lister, K., Nagels, J., Schallenberg, M., Sutherland, S., Sykes, J., Thompson, W., Vopel, K., and Wilcock, B., 2006, Ecology of Didymosphenia geminata in New Zealand-Habitat and ecosystem effects-Phase 2: National Institute of Water and Atmospheric Research, New Zealand, Client Report CHC2006-086, NIWA Project MAF06507.

Lindstrom, E.A., 1991, Use of periphyton for monitoring rivers in Norway. Application of previously obtained data to evaluate impacts of acid precipitation. In: Whitton, B.A., Rott, E., and Friedrich, G., eds., Use of Algae for Monitoring Rivers: Innsbruck, Austria, Universität Innsbruck, Institut für Botanik, p. 139-144.

Madsen, J.D., Eichler, L.W., and Boylen, C.W., 1988, Vegetative spread of Eurasian water milfoil in Lake George, New York: Journal of Aquatic Plant Management, v. 26, p. 47_50.

McNyset, K.M. and Julius, M.L., 2006, Potential geographic distribution of Didymosphenia geminata (Lyngbye) M. Schmidt in North America based on ecological niche models: [abs.] U.S. Environmental Protection Agency, www.epa.gov/region8/water/abstracts/McNyset\%20\&\%20Julius_AFS.pdf.

Metzeltin, D., and Lange-Bertalot, H., 1995, Kritische Wertung der Taxa in Didymosphenia (Bacillariophyceae): Nova Hedwigia, v. 60, p. 381-405.

Noga, T., 2003, Dispersion of Didymosphenia geminata in the flowing waters of southern Polandnew sites of species occurrence in the Orawska Watershed and the Orawska Basin: Oceanological and Hydrobiological Studies, v. 32, p. 159-170.

Patrick, R., and Reimer, C.W., 1975, The diatoms of the United States, exclusive of Alaska and Hawaii, vol. 2, pt. 1: Monographs of the Academy of Natural Sciences of Philadelphia, v. 13.

Pimentel, D., Zuniga, R., and Morrison, D., 2005, Update on the environmental and economic costs associated with alien-invasive species in the United States: Ecological Economics, v. 52, p. 273 288.

Pryfogle, P.A., Rinehart, B.N., and Ghio, E.G., 1997, Aquatic plant control research: Idaho National Engineering Laboratory report, DE-AC07-94ID13223.

Rader, R.A., and Belish, T.A., 1997, Effects of ambient and enhanced UV-B radiation on periphyton in a mountain stream: Journal of Freshwater Biology, v. 12, p. 615-628.

Schindler, D.W., 1977, Evolution of phosphorous limitation in lakes: Science, v. 196, p. 260_262. 
Schneider, D.W., Ellis, C.D., and Cummings, K.S., 1998, A transportation model assessment of the risk to native mussel communities from zebra mussel spread: Conservation Biology, v. 12, p. 788-800.

Shelby, E.L., 2006, An assessment and analysis of benthic macroinvertebrate communities associated with the appearance of Didymosphenia geminata in the White River below Bull Shoals Dam: Arkansas Department of Environmental Quality, Water Planning Division Report.

Sherbot, D.M.J., and Bothwell, M.L., 1993, Didymosphenia geminata (Gomphonemaceae). A review of the ecology of $D$. geminata and the physicochemical characteristics of endemic catchments on Vancouver Island: Saskatoon, Saskatchewan, Environment Canada, National Hydrology Research Institute NHRI Contribution No. 93005.

Skabichevsky, A.P., 1983, A new species of Didymosphenia lineata (Bacillariophyta) and its variability: Botanicheskii Zhurnal, v. 9, p. 1254-1260.

Skulberg, O.M., 1982, Effects of stream regulation on algal vegetation. In: Lillehammer, A., and Saltveit, S.J., eds., Regulated rivers. New York, Columbia University Press, p. 107-124.

Skvortzow, B.W., 1935, Diatomées récoltées par le Père I. Licent au cours de ses voyages dans le Nord de la Chine au bas Tibet, en Mongolie et en Mandjourie: Publications du Musée Hoangho Paiho de Tien Tsin. Tienstsin., v. 36, p.1-43.

Skvortzow, B.W., and Meyer, C.I., 1928, A contribution to the diatoms of Baikal Lake: Proceedings of Sungaree River Biological Station, v. 1, p. 1-55.

Smol, J., and Stoermer E.F., eds., 1998, The diatoms-Applications for the environmental and earth sciences: Cambridge, Cambridge University Press.

Stoddard, J.L., Peck, D.V., Olsen, A.R., Paulsen, S.G., Van Sickle, J., Herlihy, A.T., Kaufmann, P.R., Hughes, R.M., Whittier, T.R., Lomnicky, G., Larsen, D.P., Peterson, S.A., and Ringold, P.L., 2005, Ecological assessment of western streams and rivers: Corvallis, Oregon, U.S. Environmental Protection Agency.

Stoermer, E.F., Qi, Y.Z. and Ladewski, T.B., 1986, A quantitative investigation of shape variation in Didymosphenia (Lyngbye) M. Schmidt (Bacillariophyta): Phycologia, v. 25, p. 494-502.

Strayer, D.L., Powell, J., Ambrose, P., Smith, L.C., Pace, M.L., and Fisher, D.T., 1996, Arrival, spread, and early dynamics of a zebra mussel (Dreissena polymorpha) population in the Hudson River estuary: Canadian Journal of Fisheries and Aquatic Research, v. 53, p. 1,143_1149.

Subakov-Simić, G. and Cvijan, M., 2004, Didymosphenia geminata (Lyngb.) M. Schmidt (Bacillariophyta) from the Tisa River (Serbia)_-Its distribution and specific morphological and ecological characteristics: Algological Studies, v. 114, p. 53-66. 
Sutherland, D., Biggs, B., Blair, N. Bourstead, N., Kelly, G., and Sykes, J., 2005, Benthic survey of the Waiau Arm to determine the distributional extent of Didymosphenia geminata: National Institute of Water and Atmospheric Research, New Zealand. Client Report: CHC2005-118, NIWA Project: MEL06505.

Vitousek, P.M., D’Antonio, C.M., Loope, L.L., Rejmánek, and Westbrooks, R., 1997, Introduced species: A significant component of human-caused global change: New Zealand Journal of Ecology, v. 21, p.1-16.

Wellnitz, T.A., Rader, R.B., and Ward, J.V., 1996, Importance of light and nutrients in structuring an algal community in a Rocky Mountain stream: Journal of Freshwater Biology, v. 11, p. 399413.

Whitton, B.A., and Crisp, D.T., 1984, Tees, Pp. 146-178 In: Whitton, B.A., ed., Ecology of european rivers: Oxford, Blackwell Scientific Publications, p. 146-178. 


\section{Glossary}

acid neutralizing capacity (ANC): A water chemistry measure that gives an indication of the ability of a water sample to counter the effects of acid without changing its $\mathrm{pH}$. Water low in ANC may easily become acidic, while waters high in ANC are much more resilient. ANC is a measure similar to alkalinity, which is a measure of the buffering capacity of a water sample.

apical porefield: A structure that is part of the silica cell wall of diatoms. The apical porefield is an area of very fine pores, through which the mucilaginous stalk is secreted. Didymosphenia geminata has a single apical porefield on one end of each valve.

ash free dry mass (AFDM): A measure which indicates the amount of organic material present in a sample.

benthic or benthos: Refers to the bottom surface of a stream, river, or lake. The aquatic organisms that live in, on, or near the bottom surface are termed benthic organisms and they inhabit the benthos. Benthic organisms may include macroinvertebrates, algae, bacteria, fungi, clams, worms, and anything else that inhabits the bottom.

chlorophyll a: Chlorophyll is the primary pigment used by plants to obtain energy from the sun through photosynthesis. Chlorophyll $a$ is a specific form of the chlorophyll molecule found in photosynthetic algae. The amount of chlorophyll $a$ in a stream gives an indication of the amount of algal biomass present. High amounts of algal biomass are usually considered undesirable and indicative of increased nutrient loads.

chrysolaminarin ( $\$ 1,3$ linked glucan): A molecule produced by some groups of algae including the diatoms. The material is composed of modified glucose, functions as a food reserve, and is stored within the cell.

cymbelloid: Referring to group of freshwater diatoms within the Family Cymbellaceae. Cymbelloid symmetry is typically asymmetrical to both primary axes (the cells are crescent moons in shape). Although D. geminata is a member of this group (Kociolek and Stoermer, 1993), it does not share the characteristic symmetry.

EDTA or ethylenediamine tetraacetic acid: A specific molecule that binds strongly to ions in a solution. In the example given here, EDTA is used to bind and separate fractions of the diatom stalk.

eutrophic: Waters that are high in nutrients, specifically phosphorus and nitrogen, are considered eutrophic. High concentrations of phosphorus and nitrogen often lead to correspondingly high algal productivity and biomass.

extracellular: Material that is located outside the boundaries of the cell wall. In the example of $D$. geminata, the stalk is produced within the cell but is then excreted outside the cell wall. 
gomphonemoid: Referring to group of freshwater diatoms within the Family Gomphonemaceae. Gomphonemoid symmetry is typically symmetrical to the apical axis, and asymmetrical to the transverse axis (the cells are club shaped). Although D. geminata is often included in this group because it has gomphonemoid symmetry, Kociolek and Stoermer (1993) demonstrated it is a member of the cymbelloid lineage.

invasive species: Any species, including its seeds, eggs, spores, or other biological material capable of propagating that species, that is not native to that ecosystem; and whose introduction does or is likely to cause economic or environmental harm or harm to human health.

molecular markers: Specific sequences of genetic material (DNA) that are used to characterize or differentiate organisms.

mucopolysaccaride: A complex chain of molecules primarily composed of sugar molecules linked together to form a chain. The diatom stalk is composed of mucopolysaccarides.

nuisance bloom: The term "bloom" is traditionally applied to planktonic algae that form growths in lakes or oceans. It is not a "bloom" in the sense of flowering plants. Here, the term "nuisance bloom" is applied to the condition that $D$. geminata creates in streams because the growths threaten the diversity of other species, aquatic ecosystem function, or economic activities dependent on flowing waters.

oligotrophic: Waters that are very low in nutrients, specifically phosphorus and nitrogen, are considered oligotrophic. Such low nutrient waters are usually low in algal productivity and biomass.

periphyton: Although the strict definition of periphyton is "growing on or around plants", the term is used to apply to photosynthetic organisms (mostly algae) growing on surfaces in aquatic systems. The algae in periphyton is an important source of food for organisms of higher trophic levels (for example, macroinvertebrates, fish).

plankton: Organisms that have little or no ability to control their position within a body of water, that is, they are suspended in the water column. Plankton may be photosynthetic and plant-like (phytoplankton), heterotrophic and animal-like (zooplankton), or composed of bacteria (bacterioplankton).

raphe: A structure in the silica cell wall of some diatoms. Diatoms that possess this slit-like structure are able to move on the surface of substrates. Because these cells can move, they have some ability to select preferred habitats for growth. Didymosphenia cells possess a raphe which is functional before cells anchor to a substrate via a stalk.

valve: The siliceous part of the diatom cell wall is composed of two parts, termed valves. Together, the two valves are called a frustule. Diatom valves are often highly ornamented and diatom taxonomy is primarily based on the morphology of these structures. 
visual biovolume index: A measure developed in New Zealand to assess the impact of $D$. geminata cells and stalks to a stream ecosystem. The index is a measure of the percent cover of algal mat in a stream transect multiplied by the thickness of the algal mat. 


\section{Appendix 1: Additional Resources}

Available resources for more information about Didymosphenia geminata and invasive aquatic species:

\section{Internet Resources}

Biosecurity New Zealand

www.biosecurity.govt.nz/didymo

United States Environmental Protection Agency

www.epa.gov/region8/water/didymosphenia/

Federation of Fly Fishers

www.fedflyfishers.org/conInvasiveSpecies.php

Stop Aquatic Hitchhikers

www.protectyourwaters.net/

Global Invasive Species Database

www.invasivespecies.net

State of Arkansas Department of Environmental Quality

www.adeq.state.ar.us/water/didymo.htm

New Zealand Fish and Game---Video clip

www.southlandfishgame.co.nz/didymo.htm

\section{Report Occurrences}

Report suspected growths of Didymosphenia by collecting a small sample (put a pinch of the material in a vial with ethanol or in a folded business card). Label samples with the date, latitude, and longitude (provide detailed accurate site information). Send reports and samples to:

Dr. Sarah Spaulding

U.S. Geological Survey

1595 Wynkoop Street

Denver, Colorado 80202 U.S.A

Email: sarah.spaulding@usgs.gov

Tel: $\quad 303-312-6212$ 


\section{Appendix 2: Scientific Meetings}

Presentations at scientific meetings are a vital form for communication of scientific findings. Issues stemming from $D$. geminata have stimulated a rapid and broad scope of research interests. Scientists have presented talks or posters on D. geminata at the following national and international scientific conferences:

\begin{tabular}{|c|c|c|c|}
\hline Conference & Date & Location & Link \\
\hline $\begin{array}{l}\text { Didymosphenia Symposium, } \\
\text { American Fisheries Society }\end{array}$ & May $15-16,2006$ & $\begin{array}{l}\text { Bozeman, Mont., } \\
\text { U.S. }\end{array}$ & $\begin{array}{c}\text { http://www.epa.gov/region8/water/ } \\
\text { events.htmldidymosphenia/ }\end{array}$ \\
\hline $\begin{array}{l}\text { International Conference } \\
\text { Aquatic on Invasive Species }\end{array}$ & May 15-18, 2006 & $\begin{array}{l}\text { Key Biscayne, Fla., } \\
\text { U.S. }\end{array}$ & $\begin{array}{l}\text { http://www.icais.org/html/previous } \\
\text { 14.html }\end{array}$ \\
\hline $\begin{array}{l}\text { North American Benthologi- } \\
\text { cal Society }\end{array}$ & June 4-9, 2006 & $\begin{array}{l}\text { Anchorage, Alaska } \\
\text { U.S. }\end{array}$ & $\begin{array}{l}\text { http://www.benthos.org/Meeting/n } \\
\text { abs2006/index.htm }\end{array}$ \\
\hline $\begin{array}{l}\text { Phycological Society of } \\
\text { America }\end{array}$ & July 7-12, 2006 & $\begin{array}{l}\text { Juneau, Alaska } \\
\text { U.S. }\end{array}$ & $\begin{array}{l}\text { http://www.psaalgae.org/ops/psa2 } \\
\text { 006.shtm }\end{array}$ \\
\hline $\begin{array}{l}\text { Joint Conference of the NZ } \\
\text { New Zealand Ecological } \\
\text { Society and the Ecological } \\
\text { Society of Australia }\end{array}$ & $\begin{array}{l}\text { Aug 28-Sep 1, } \\
2006\end{array}$ & $\begin{array}{l}\text { Wellington, New } \\
\text { Zealand }\end{array}$ & www.vuw.ac.nz/ecology06 \\
\hline $\begin{array}{l}\text { International Diatom } \\
\text { Symposium }\end{array}$ & $\begin{array}{l}\text { Aug 28-Sep 3, } \\
2006\end{array}$ & $\begin{array}{l}\text { Irkutsk, } \\
\text { Russia }\end{array}$ & http://lin.irk.ru/ids2006/ \\
\hline $\begin{array}{l}\text { International Conference on } \\
\text { Harmful Algae }\end{array}$ & Sep 4-8, 2006 & $\begin{array}{l}\text { Copenhagen, } \\
\text { Denmark }\end{array}$ & http://www.bi.ku.dk/hab/ \\
\hline $\begin{array}{l}\text { NZ New Zealand Freshwater } \\
\text { Sciences Conference }\end{array}$ & Nov 26-3, 2006 & $\begin{array}{l}\text { Rotorua, New } \\
\text { Zealand }\end{array}$ & http://limsoc.rsnz.org/ \\
\hline $\begin{array}{l}\text { American Society of } \\
\text { Limnology and Oceanogra- } \\
\text { phy }\end{array}$ & Feb 4- 9, 2007 & $\begin{array}{l}\text { Santa Fe, N. Mex., } \\
\text { U.S. }\end{array}$ & $\begin{array}{l}\text { http://www.aslo.org/meetings.sant } \\
\text { afe2007/ }\end{array}$ \\
\hline $\begin{array}{l}\text { International Association of } \\
\text { Theoretical and Applied } \\
\text { Limnology }\end{array}$ & Aug 12-18, 2007 & Montreal, Canada & http://www.sil2007.org/ \\
\hline $\begin{array}{l}\text { International Didymosphenia } \\
\text { Workshop }\end{array}$ & Aug 19-20, 2007 & Montreal, Canada & http://www.sil2007.org/ \\
\hline
\end{tabular}




\section{Appendix 3. Media Coverage}

\section{Magazines}

Flyfisher, Fall 2006

"Dealing with Didymo"

Fly Rod and Reel, April 2006

"Short Casts: Getting to Know Didymo"

South Dakota Conservation Digest, March/April 2006

"Didymo and the Rapid Creek Brown Trout"

Biosecurity, February 2006

"Personal Responsibility Key to Stopping Didymo Spread"

High Country Angler, Winter 2006

“'Didymo': What is it, and should we be worried?"

\section{Print Articles}

Bozeman Daily Chronicle, May 16, 2006

"Algae Outbreak Threatens Rivers Around World"

Bozeman Daily Chronicle, May 14, 2006

"Scientists to Gather and Discuss Slimy Algae"

Colorado Daily, November 6, 2005

"'Rock snot' Spreading: Pesky Algae Could Threaten Waterway Ecosystems Across Country"

Denver Post, November 1, 2005

"Slime Covers Streams"

Rapid City Journal, April 14, 2005

"Algae Invader: Survey Tracks Spread of 'Thug”"

\section{Online Articles}

Montana's News Station, May 16, 2005

"Slimy Algae Draws Scientists to Bozeman"

www.kbzk.com

Vail Daily, May 182006

"Didymo Along the Gore Creek in Vail"

www.vaildaily.com 
Billings Gazette, May 18, 2006

"Slimy Alga Threatens State Rivers" www.billingsgazette.net 